\title{
A petrologist in South Africa: Frederick Henry Hatch and the Witwatersrand Goldfield
}

\author{
R.J. Howarth* \\ Department of Earth Sciences, University College London, London, WC1E 6BT
}

*Tel.: +4402083327835.

E-mail address: r.howarth@ucl.ac.uk.

Keywords:

History of geology; Gold mining; The Witwatersrand

\begin{abstract}
The English geologist, Frederick Henry Hatch (1864-1932), today mainly recalled for a textbook on igneous petrology, emigrated to South Africa, where, in the years between 1892 and 1906, he became one of the pioneers of the geology of the Transvaal and the Witwatersrand Goldfield. This article reviews his life and, in particular, his work during this period which led to his becoming a mining geologist with connections to many of the world's goldfields, set against the political background of the Boer War which influenced the course of his work.
\end{abstract}

\section{Introduction}

The English geologist, Frederick Henry Hatch (1864-1932) is today probably recalled, if at all, simply as an author of The Petrology of the Igneous Rocks, which ran to 12 editions, the later ones coauthored with the igneous petrologists Alfred Kingsley Wells (1899-1980) and Maurice Kingsley Wells (1921-1994) (1st, Hatch, 1891c; 8th, Hatch and Wells, 1926; 10th, Hatch et al., 1949; 12th, Hatch et al., 1961). However, probably the most important parts of his career took place in South Africa between the years 1892 and 1906, during which time he established a reputation as a consulting mining engineer whose work had helped to unlock the economic potential of the Witwatersrand (commonly referred to as 'the Rand') Goldfield, which was becoming the world's most productive. He is still honoured there as one of seven 'Pioneers of Witwatersrand geology,' the others being: John Storey Curtis (1845-1918), Arthur Robert Sawyer (1850?-1933), George Steuart Corstorphine (1868-1919), Edward Thomas Mellor (1868-1940), Arthur William Rogers (18721946), and Robert Burns Young (1874-1949) (Geological Society of South Africa [undated]; Anhaeusser, 1997). Hatch was also unusual in holding the Presidency of both the Geological Society of South Africa (GSSA), in 1905, and that of the Institution of Mining and Metallurgy (IMM), 
London, in 1914. In his Presidential address to the IMM, he noted that the term 'mining geologist' was by then being increasingly used 'to designate a mining engineer strong on the geological side, or, what in practice amounts to the same thing, a geologist who has specialised in mining work' (Hatch, 1914a, p. xlix). The latter precisely reflects his career.

Hatch was born in London on 7 March 1864, the eldest of the seven children of Henry Hatch, a wealthy Oxford merchant, and his common-law wife, Elizabeth Collier (Howarth, 2004). Schooled privately in London and Paris, he entered University College London in 1879, where he studied general science and chemistry, and his interest in geology was awakened by the lectures of the petrologist, Thomas Bonney (1833-1923). Curiously, although in later life Hatch claimed to have been awarded a 'gold medal and the Tuffnell Scholarship for proficiency in Analytical Chemistry' (e.g. Hatch, 1891d, which is also quoted in Jones, 1993), according to London University records, although he came second in the first division in the Intermediate Science exam of 1883, with Honours in chemistry, he was not actually given the award nor the scholarship, as these were usually conditional on a student's intention to sit for a degree two years later (J.C. Walworth, pers. comm., 1991) and he transferred to the Rheinische Friedrich-Wilhelms-Universität Bonn, Germany, that October. There he studied geology, mineralogy and mining under Arnold von Lasaulx (1839-1886); crystallography and mineralogy under Carl Hintze (1851-1917); geography under Johannes Rein (1835-1918); chemistry under Friedrich Kekulé (1829-1896); botany under Frederico Johow (18591933); and philosophy under Johann Witte (1800-1883). From April 1885 until July 1886, he worked as a University Assistant to Lasaulx (Hatch, 1885a, 1885b), teaching and arranging material in the museum of the Institute of Mineralogy. He submitted his thesis, a petrological study of the andesites of the Arequipa region, south-western Peru (Hatch, 1886) in December 1885, and obtained his PhD (in Mineralogy, Chemistry and Geology) 'Magna cum laude' [with great honour] in March 1886 (T. Becker, pers. comm., 1996).

Following his return to England in July 1886, he joined H.M. Geological Survey of Great Britain in London as a 'Temporary Assistant Geologist (Petrologist for England and Wales),' regarded as 'undoubtedly the best trained of the younger petrologists in Britain' (Flett, 1937, pp. 120121), cataloguing and arranging the reference collection of rocks in the Survey's Geological Museum in London (Hatch, 1888a) but mainly working, sometimes in the field, but chiefly in the laboratory, examining the microscopic petrography, and occasionally chemistry, of igneous rocks from England, Scotland and Ireland (Hatch, 1888b, 1889a,1889b, 1889c, 1890, 1891a,1891b, 1892a,1892b). A prolific worker, in his spare time he also made himself 'proficient in physical geography, stratigraphy and historical geology' (Hatch, 1891d). However, in 1888, Jethro Teall (1849-1924) moved from a Fellowship at St. John's College, Cambridge, to become Petrographer at the Survey and Hatch now worked under him, examining rocks sent in to the Survey offices from the field (Hatch, 1888c, 1888d; Gunn et al., 1897, pp. 119-120) or from elsewhere (Hatch, 1889d). He also supplied a glossary of descriptive terms for Teall's British Petrography (Hatch, 1888e) and they both attended the 4th International Geological Congress in London in 1888. Looking back at the history of the Geological Survey, the Sir Edward Bailey had no doubt that 'Hatch's most important single contribution to British geology' was the discovery of the extrusive volcanic rocks limburgite, and nephelinephonolite in the Carboniferous rocks of Scotland (Hatch, 1892a, 1892b) on the grounds that the latter 'finally broke down the defences of the Continental school, which advocated significant differences between Cainozoic and pre-Cainozoic igneous rocks [claiming] that nepheline-phonolite .... is exclusively Cainozoic' (Bailey, 1952, p. 181).

Hatch's work with Teall resulted in him meeting Mary Randall (1866-1921), who lived next door to Teall's house in Kew, and they married in 1890 (Fig. 1), but it seems that Mary was a 
reluctant bride, having been brow-beaten into marrying him by her future mother-in-law (Mrs. P. Souave, pers. comm.). Their first child, Philip was born in February 1892.

Quite apart from his Survey reports, Hatch found time to publish translations from the German of the diagnostic Petrographical Tables of Karl Heinrich ['Harry'] Ferdinand Rosenbusch (1836-1914) (Rosenbusch, 1888, 1890) and a book by the Hungarian geologist, Tivadar Posewitz (1850-1917), on the geology and mineral resources of Borneo (Posewitz, 1889, 1892; Hatch, 1892c), as well as his own Introduction to the Study of Petrology (1891c) which became the Textbook of Petrology (1892d), and Mineralogy (1892e). He also acted as a Secretary for the Geology section of the British Association for the Advancement of Science (BAAS) meeting in Leeds in the summer of 1890 and as an Instructor in Geology for the Royal



Figure 1. Frederick Hatch at the time of his marriage in 1890 (courtesy of Mrs. J. McLachlan). Geographical Society (1890-91), imparting geological knowledge to intending explorers.

\section{Africa beckons}

Hatch's interest in gold may have been awakened in the course of his translation of Posewitz's (1889) book, which described the occurrence and mining of gold in Borneo (Posewitz, 1892, 312-379) and, from his position in the Geological Survey, he would probably have been aware of a paper (Sawyer, 1889) by the English mining engineer, A.R. Sawyer, on the Witwatersrand Goldfields, based on a brief visit he had made to the Transvaal in June 1889 shortly before emigrating there (Anhaeusser, 1997, 115). Later that year, at the $59^{\text {th }}$ Annual Meeting of the British Association for the Advancement of Science in Newcastle-upon-Tyne, Hatch spoke On the Lower Silurian Felsites of the South-East of Ireland (Hatch, 1890), and he might well have attended a subsequent talk by the American civil engineer, Edward Dorsey, On the Witwatersrand Goldfields (Dorsey, 1890).

Hatch would doubtless also have heard a far more detailed exposition of the geology of the Witwatersrand given to The Geological Society, London, by the English geologist, Walcot Gibson (1864-1941) in April 1892. Formerly a student of the structural geologist, Charles Lapworth (1842-1920), at Birmingham University, Gibson had been working in southern Africa since 1889 , and believed that much still needed to be done to understand the stratigraphy and structure of the Witwatersrand basin in order to reduce the risks in starting up new mining ventures. He thought it possible that there may have been repetition of the

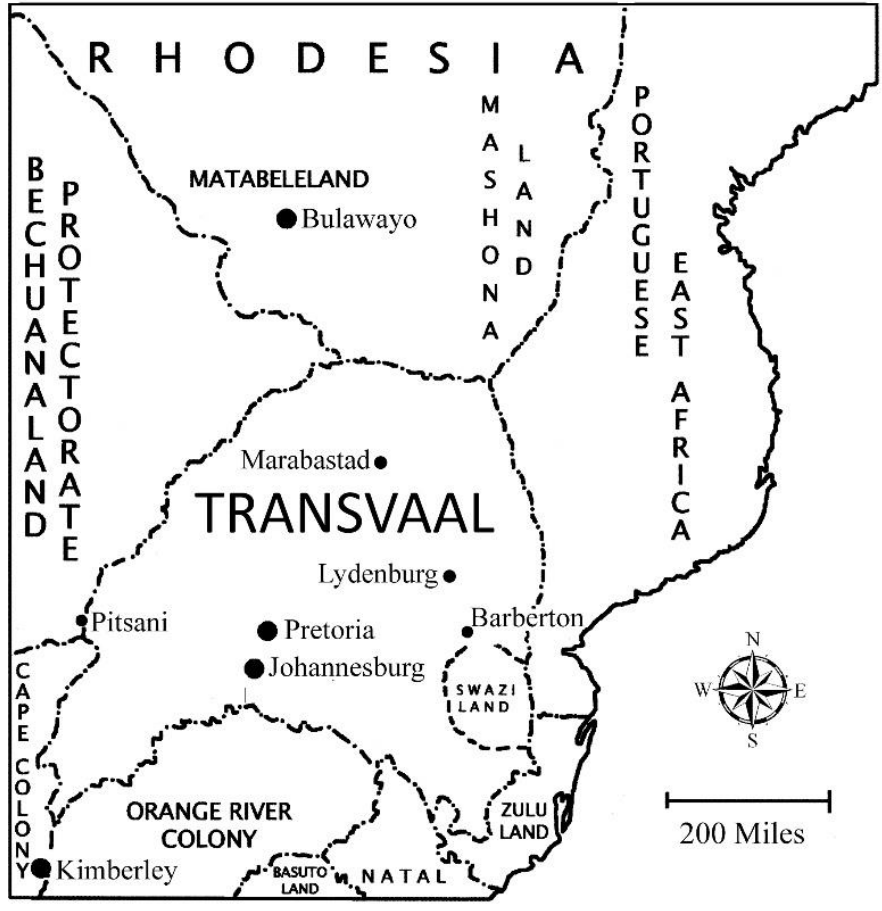

Figure 2. Geographical setting. Political boundaries are as in 1902. 
gold-bearing beds by 'overthrusting and shearing' and, in the ensuing discussion, George Attwood (1845-1912) recognised that the geological setting of the basin appeared to be unique and, consequently, of particular interest.

It seems likely that Hatch agreed with this sentiment and, perhaps spurred on by his wife's view that 'a career in the civil service, however distinguished, did not offer the prospects commensurate with the talents she believed her good-looking husband possessed' (Mrs. J. McLachlan, pers. comm.), he sought the advice of Algernon Charles Moreing (1856-1942), a senior partner in Bewick, Moreing \& Co., one of London's leading firms of consulting mining engineers. Subsequently, to the surprise of the Survey, Hatch resigned his position that summer (Anon., 1893a, pp. 247, 248) and, sponsored by Moreing and Frederick Rudler (1840-1915), Curator and Librarian of the Museum of Practical Geology, he was elected to Associate membership of the IMM in July 1892, giving his future address as a post-office box in Johannesburg.

Hatch, his wife and their son, sailed for South Africa, where he was to embark on a new career with the South African Trust \& Finance Co. (SATF), established in 1890 by the English entrepreneur 'Barney' [Barnett] Barnato (1851-1897), who had made his fortune in the diamond fields (Jackson 1970). They may well have made the voyage in the company of the English mining engineer, William Young Campbell (d. 1899), joint manager of the SATF and with whom Hatch would be working, who sailed out in late July 1892 (Anon., 1892a). Following a journey of some 25 days at sea from Southampton to Cape Town, then 32 hours by train to Kimberley (Fig. 2) and a further 53 hours by bullock-drawn coach (W.C.B., 1890 , p. xix), they would have arrived in Johannesburg (passenger train-travel to Johannesburg would begin that September). They set up their new home in Bertrams Town (Fig. 3), a suburb east-north-east of the town centre and their second son, Laurence, would be born there in November 1893.

\section{Discovery of the Witwatersrand Goldfield}

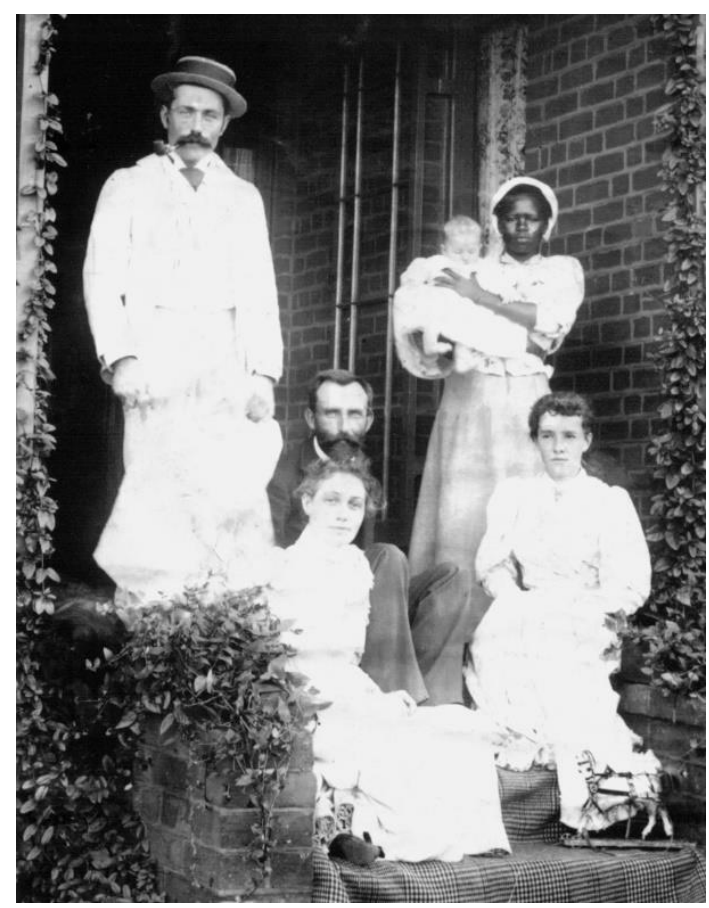

Fig. 3. Hatch (standing, left) and his family in Bertrams Town, Johannesburg, c. 1892. Seated: Emily, his sister (left), Jack O'Gorman Lalor (his assistant), Mary (right); the servant is holding Philip (courtesy of Mrs. J. McLachlan).

The Cape Colony had been formally ceded to Britain by Holland in 1814, and between 1833 and 1837 the Boer Voortrekkers, Afrikaans-speaking farmers and their families, journeyed northwards to the lands beyond the Vaal River to escape British rule and establish the Zuid Afrikaansche Republiek [South African Republic] (ZAR). Its independence was eventually recognised by the British in the Sand River Convention of 1852 (Nutting, 1970). 
By 1851, the Witwatersrand was regarded (Gray, 1937, p. 16) as the northern side of a range of hills at an elevation of around $6000 \mathrm{ft}(1830 \mathrm{~m})$, which divides the watercourses flowing south into the Vaal River (which forms much of the border between the Transvaal Colony and the Orange River Colony) from those directed northwards, towards either the eastward-flowing Limpopo River (which defines much of the northern border of the Transvaal with Bechuanaland and Matabeleland), or to the Olifant or Lepalule (now Lepelle) River which eventually exits eastwards towards the Indian Ocean, halfway along the border with Portuguese East Africa (Figs. 2, 4). The name Witwatersrand, originally Witt Waters Rand [Ridge of white waters], derives from the way the descending watercourses appeared from a distance.

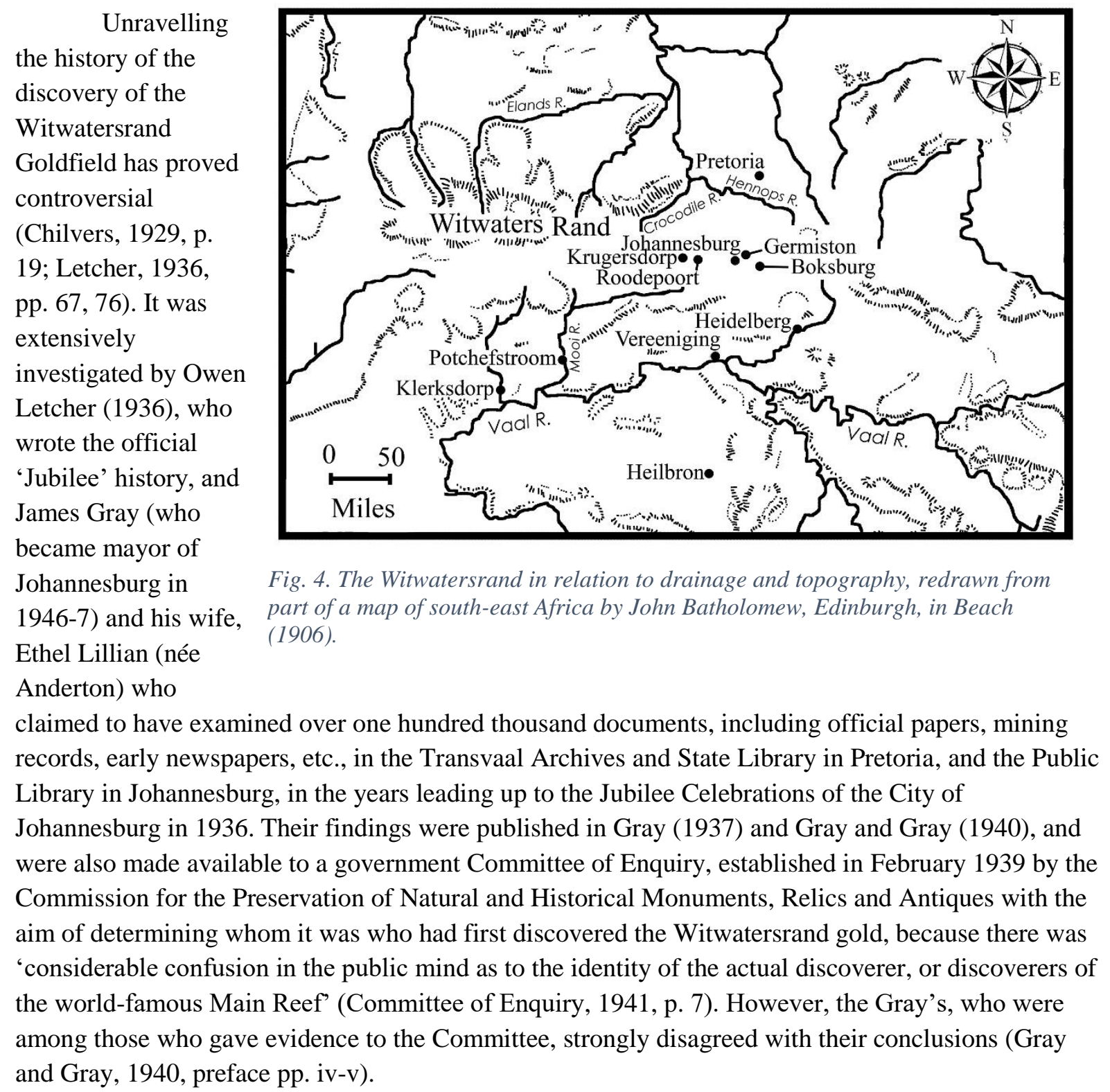

More recent historical reviews include Antrobus (1986), De Jager (1986), Lednor (1986), Werdmüller (1986) and Handley (2004). Handley (2004, p. 20) alleges that, despite their extensive research, the Grays were biased in their view as to whom the principal discoverers actually were, and selective in their presentation of the available evidence. He argues (ibid., p. 9) that a distinction should always be made between: (i) an initial reconnaissance discovery: 'the recording of the presence of a mineral or rock in an area for the first time in itself does not constitute a true discovery, 
but the recording in passing of indications [his italics] can create an impetus for further search;' and (ii) discovery: 'the location of a mineral or rock in a hitherto unknown field, its evaluation in a particular structure or formation, demonstration of payability and indications of extension to the initial discovery. The discovery should lead to almost immediate development, not necessarily by the discoverer.' Handley's views agree with those of the 1939 Committee of Enquiry, whose members were the Right Hon. Francois Stephanus Malan (1871-1941), President [Speaker] of the Senate; Prof. Louis Fernand Maingard (1884-1986), linguist; Dr. Sidney Henry Haughton (1888-1982), Director of the Geological Survey; and Prof. Leo Fouché (1880-1949), historian. They decided that 'mere reports of the finding of gold - without the least attempt to exploit that find, and totally devoid of any practical result - while they may be of some academic interest cannot reasonably be regarded as a subject for official investigation .... The word "discovery" .... applied to the finding of gold-bearing reefs, means, and should be taken to mean, not merely the act of finding or exposing to view such reefs, but also the disclosure or publication of such finds, and the consequent opening up of such reefs - leading eventually to actual exploitation (Committee of Enquiry, 1941, p. 8).

The earliest reports of reconnaissance discoveries include a possible find of gold by a blacksmith, Karel (?Carel) Kruger while on a hunting expedition to the Transvaal in 1834 (Webb, 1903, quoted in Grey and Grey, 1940, pp. 13 ); and a find of alluvial gold in 1852 on a farm Groote Paardkraal (Fig. 5) by John Henry Davis (originally born Davies in Cardiff,



Fig. 5. Locations of principal farms mentioned in the text (modified from Committee of Enquiry, 1941, pl. 1). Those coloured grey were proclaimed Public Diggings in September 1886. The town of Johannesburg was officially established, on what was the farm of Randjeslaagte, in October 1886.

South Wales; D.D.,

1905; Letcher, 1936, pp. 519-520), who had some knowledge of mineralogy, having prospected for gold and diamonds in Brazil. This occurrence may have been related to a similar find on nearby Witpoortje farm in 1887 (Fig. 5; Letcher, 1936, p. 37; Gray and Gray, 1940, pp. 2-3).

Having prospected for gold in California and Australia during 1849-52, Pieter Jacob Marais (1827-1865) returned to South Africa and, in October 1853, found alluvial gold near the confluence of the Jukskei (Yokeskey) and Crocodile Rivers (Fig. 5). On the strength of this, he was appointed an official prospector by the Volksraad in December 1853 (a translation of his contract is in Lezard, 1937, pp. 25-27), but subsequently unable to repeat his earlier success, he left his post at the end of 
August 1855 (Preller, 1935, quoted in Gray and Gray 1940, pp. 4-5, 17; Lezard, 1937, pp. 29-31; Committee of Enquiry, 1941, pp. 10-13).

[Robert Oliver] Godfray Lys (d. 1936) was interviewed during the preparation of books by both Letcher (1936) and Lezard (1937). He recalled that on his family's arrival in the Rand in 1856, his father, Lieut. John Robert Lys (1829-1880), recognised the presence of 'pudding stone,' a conglomerate consisting of vein-quartz pebbles in a fine matrix, at what became known as Lys' vlei [marsh], near to what would, in 1886, become the town of Germiston (Fig. 4). Such rock (Fig. 6; Young 1917) came to be known by the Afrikaans word 'banket' [banquet] or 'almond rock,' because of its supposed resemblance to a Dutch almond-filled pastry of that name. By crushing a portion of it and panning it, his father later showed that it was gold-bearing. This was subsequently corroborated by the



Fig. 6. Lithograph of specimen (c. natural size) of auriferous 'banket' from the Angelo mine, East Rand, established in 1895 (De Launay 1896, fig. 2). [A black and white photograph is in Hatch and Corstorphine (1905a, fig. 31); for colour photographs, see Hocking (1986, unnumbered fig. opp. p. 40), Werdmüller (1986, pl. II-1) or Handley (2004, figs. 3.1c-3.8c)]. German explorer and geologist, 'Carl' (Karl Gottlieb) Mauch (1837-1875), who visited the ZAR in 1866, and to whom J.R. Lys showed the pudding stone at Lys' vlei in 1866, while Mauch was staying with the family when on his way to Tati (which lies close to the southern border of Matabeleland, in what is now Botswana; Fig. 2), where he would find gold in 1868 (Letcher, 1936, pp. 39, 520). Mauch also showed them a reef (which would later be recognised as part of the Main Reef) on the farm Driefontein, some three-quarters of a mile east of Lys' vlei (Fig. 5; Letcher, 1936, pp. 38-41). However, he did not pursue exploration of the 'pudding stone,' as he regarded exploring Tati as the greater prize (Letcher, 1936, pp. 38-9). Based on notes he made during his year's visit (possibly in 1867; Rogers, 1937, p. 83) Mauch drew the first geological map of the Transvaal (reproduced in Harger, 1934; see also Lombaard, 1934) at a scale of about $70 \mathrm{mi} / \mathrm{in}(1: 4,435,200)$.

As a result of a steady decline in gross revenues to the ZAR (Letcher, 1936, p. 47) in December 1870 it was decided by the Volksraad, in an effort to raise income for the Government, to 'grant a reasonable reward for the finding of precious stones and precious metals, such as gold and silver, etc.' (Werdmüller, 1986, p. 14). The subsequent finding of gold reefs in the Murchison Mountains and at Eersteling, near Marabastad, in the northern Transvaal Colony in 1870; followed by alluvial gold in the Lydenberg area in 1871; and, in what later became the De Kaap goldfield, near Barberton, in 1874 (Fig. 2) excited a general interest in prospecting for gold (Hatch, 1894). This activity was reflected in the Witwatersrand also (Letcher, 1936).

Following discovery of alluvial diamonds in the Orange River, south of Kimberley, 'wet diggings' had begun on the banks of the Orange and Vaal Rivers in 1867. Frederick 'Fred' Pine Theophilus Struben (1851-1931) worked on the Vaal that year then, following the discovery of the Kimberly diamond field in 1870, he and Marais joined his brother, Hendrik 'Harry' Wilhelm Struben (1840-1915), there. Shortly after their return to the family home, The Willows, near Pretoria (Fig. 5), which H. Struben, already a wealthy businessman, had purchased in 1862, the latter was asked by Marais to join him in a venture in the Lydenberg district (Fig. 2). They purchased the Ponies Krantz and Drie Kop farms on which, shortly after, alluvial gold was found and the Pilgrims Rest Goldfield 
established, but sold them before the first Sekukuni War broke out in 1876 (Struben, 1920, p. 192; Letcher, 1936, pp. 49-50; Rogers, 1937, p. 109).

In 1874, both alluvial and reef-based gold were found on the farm Blaauwbank in the West Rand (Fig. 5) by an Australian prospector, Henry Lewis. Subsequently, together with Marais and others, the first gold-mining company in the Witwatersrand area, the 'Nil-Desperandum Co-operative Quartz Company' was floated in January 1875 to work the reef, but the venture ended in failure in 1882 (Committee of Enquiry, 1941, pp. 13-14). Tobias Maré, who had learnt prospecting methods from Mauch, reputedly found gold-bearing reef on the farms Wilgespruit and Braamfontein (Fig. 5) in 1876 (Letcher, 1936, pp. 52) and, in 1881, a quartz reef was found by Fanie Minnaar on the farm Kroomdraai (Fig. 5). A syndicate was formed by Minnaar with Jan Gerritze Bantjes (1843-1914), and others in 1882 to work the farm, but it was abandoned by December1883 and was subsequently taken over by a syndicate formed by Henry Nourse (1857-1942) with others (J.G. Bantjes, 1903, quoted in Letcher, 1936, pp. 68-70, 73).

When F. Struben eventually came back to the family home from the northern Transvaal in 1883, he initially successfully prospected for gold and copper in the Rooiberg district, some $75 \mathrm{mi}$ $(120 \mathrm{~km}) \mathrm{NNW}$ of Pretoria, but could not raise the capital to exploit the find (Struben, 1920, p. 192). Following his return, he began work locally and found the first trace of vein-quartz reef (which he named 'Dana reef') on Sterkfontein farm (Fig. 5) in January 1884. The brothers formed the 'Sterkfontein Junction Mining Syndicate' in March 1884. That April, F. Struben noted the first banket on Groot Paardkraal (Fig. 5; where Davis had reputedly found gold in 1852). He subsequently systematically traced the beds to the east, coming across more banket but, because he believed the vein-quartz reef on Wilgespruit to be more promising, he persuaded his brother to purchase both farms that September. By December 1884, he was mining 'Confidence Reef,' but he continued to search for banket during 1885 (F. Struben 1896 mss., quoted in Committee of Enquiry, 1941, p. 17; Struben 1920, pp. 192-3).

Aware of the severe financial problems the Volksraad were still having (see Nutting (1970) for political background), H. Struben gave a presentation to them in June 1885, exhibiting gold from Confidence Reef, explaining how his brother had 'traced the reef' for over $12 \mathrm{mi}(19 \mathrm{~km})$, sunk shafts to a depth of $50 \mathrm{ft}(15 \mathrm{~m})$ and cut tunnels, showing that the reef increased to as much as $12.5 \mathrm{ft}(4 \mathrm{~m})$ width at depth (unnamed Pretoria newspaper account, 5 June 1885, quoted in Letcher, 1936, p. 72). He successfully encouraged them to open up mining as a way to boost income to the exchequer. In December 1885, the brothers imported a five-stamp crushing-battery from England, and recovered the gold by amalgamation, a process in which the crushed ore, mixed with water is passed over copper plates coated with mercury (Struben, 1920, pp. 193-197; Lezard, 1937, pp. 36-39).

Following the widely-publicised discovery of a 'rotten reef on the farm of Mr. Boshoff.... very rich in gold' in the Heidelberg district by a prospector, Henry Baumann, in 1885 (Harrismith Advertiser, 17 Aug. 1885, quoted in Gray, 1937, pp. 57-58, who suggests it was probably on Reitvlei farm, which then adjoined Turffontein, Fig. 5), it began to be generally realised that the weathered banket might be a useful source of gold, but F. Struben had already recognised this having, in April 1885, compiled a sketch-map (reproduced in Gray and Gray, 1940, plate 12; and in colour on the rear of the book cover of Handley, 2004), showing the exposures of both banket and quartz-vein reefs in the district, which he had sent to his sister-in-law. It was unfortunate that the banket reefs in the area in which he had started prospecting were not nearly as rich as those to the east were to prove to be, and 'Confidence reef' appeared to offer better prospects. 
In the course of his work at the stamp battery, F. Struben was assisted by his old friend G. Lys; he also gave temporary work to an itinerant builder, George Walker (1853-1924), and carpenter, George Harrison, who were heading for the Barberton Goldfield; as well as advising J. Bantjes, his brother Hendrik, and a local farmer and friend of the Struben family, Dirk Geldenhuis (of Wilgespruit), on where to look for banket. Subsequently, Harrison and Walker went on to work on the nearby farm of Langlaagte (Fig. 5), where they befriended black-smith, George Honeyball (18571949), nephew of the owner. The subsequent accidental discovery, in March 1886, of what would prove to be the gold-rich Main Reef Leader (the term 'leader' came to be applied to the individual beds of banket), the foundation of the Witwatersrand Goldfield, on the farm Langlaagte (Fig. 5), has proved very controversial: Werdmüller (1986, p. 14) argues that the Strubens, although aware of conglomerate occurrences, 'persisted in prospecting the northern slopes of the hills where at best they could only find yet another auriferous vein quartz of limited extent .... it is strange that they did not search more systematically for auriferous conglomerates along the southern slopes,' but there are others (Chilvers, 1929, pp. 19-20;

Committee of Enquiry, 1941, p. 49; Handley 2004, pp. 18-20) who suggest that although Walker, and perhaps Harrison, stumbled across the Main Reef while quarrying the stone for a cottage Honeyball was building for the owner of a portion of Langlaagte, they 'failed to follow up their work and sold their claims,' hence the honour of being regarded as 'discoverer of gold in the Witwatersrand System' should go to

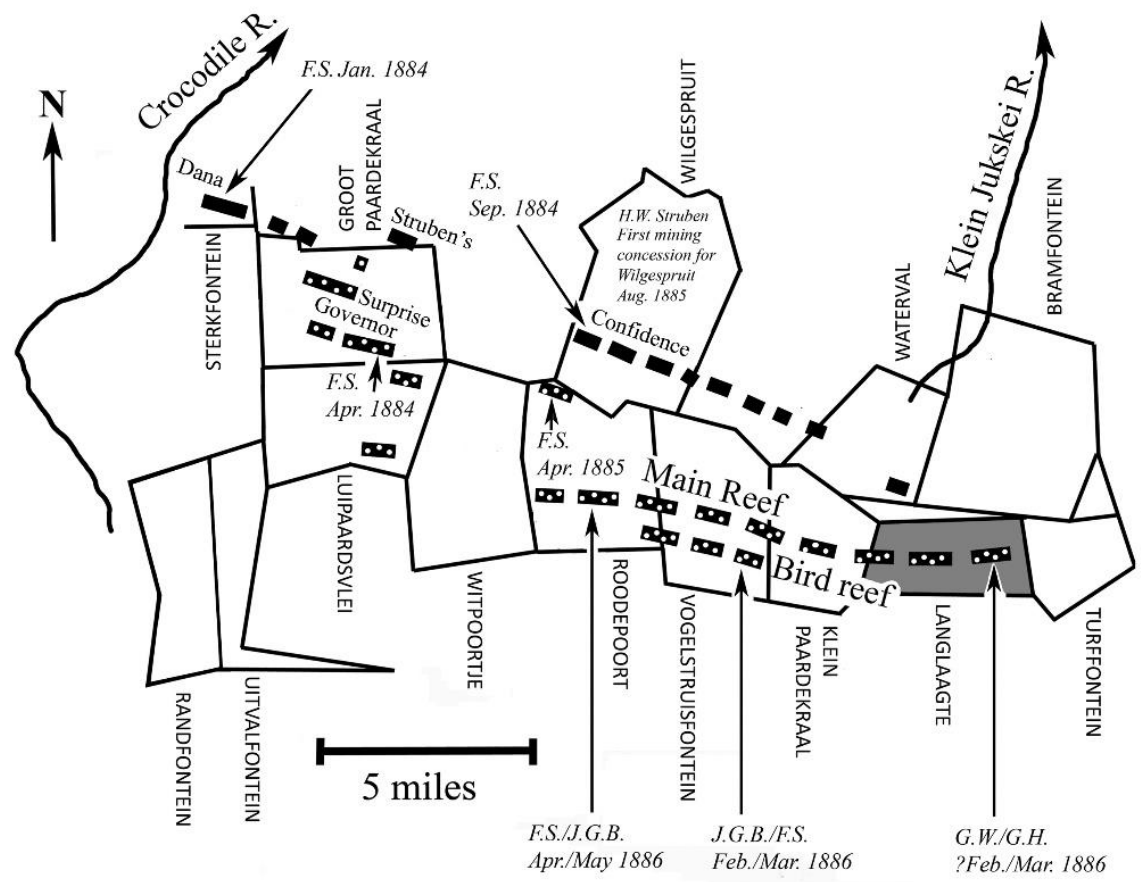

Fig. 7. Sketch map to show chronology of prospecting by the Struben brothers and others (1884-87) in the west Witwatersrand. The width of the map is approximately $20 \mathrm{mi}(32 \mathrm{~km})$. Solid black: quartz-reefs; black with white dots: banket. F.S., Fred Struben; J.G.B., J.G. Bantjes; G.W., George Walker; G.H., George Harrison. The beginnings of the Jukskei and Crocodile Rivers at the confluence of which Marais found traces of gold in 1853 are also shown (see Fig. 5). Grey-coloured farm (Langlaagte) is first property purchased by J.B. Robinson, July 1886. 'Governor' reef later became known as 'Government' reef. Farm boundaries from McLea (1909?) with additional information from Gray and Gray (1940, pl. 13) and compilation by D.A. Pretorius in Handley (2004).

F. Struben (Handley,

2004, p. 20; see also discussion in Committee of Enquiry, 1941, pp. 31-36). A detailed chronology of the early discoveries, and subsequent development, in the district up to 1887, compiled by the late Prof. D.A. Pretorius (1925-1998) is given in Handley (2004, pp. 12-18) and the essentials are incorporated in Fig. 7.

In July 1886, a produce merchant from Kimberley, Fred W. Alexander, met Bantjes, almost by chance, at Potchefstroom, and was persuaded by him to visit the Rand. He did so on 7 July, and took 
samples of the gold-bearing banket back to Kimberley, which he exhibited, together with panned gold, in his shop, and brought it to the attention of the diamond magnates (Letcher, 1936, p. 83). Word spread rapidly, and the men who had made their fortunes in the Kimberly diamond fields began to take an interest the area. First among them was the South African entrepreneur, Joseph Benjamin 'JB' Robinson (1840-1929; a Baronet from 1908) who, financed by Alfred Beit (1853-1906), purchased the Langlaagte and Randfontein estates later in July; others included: Cecil Rhodes (18531902), Carl Hanau (1855-1930), Henry Nourse (1857-1942), Abe Bailey (1864-1940), and Barnato. By the end of August, some 3,000 prospectors were engaged in activity along a strike-length of some $30 \mathrm{mi}(48 \mathrm{~km})$ of the Main Reef Series outcrops, from Krugersdorp in the west to Boksburg in the east (Fig. 4; Letcher, 1936, p. 80), and on 8 September, the Government of the ZAR declared 'Public Diggings' on the farms Roodepoort, Vogelstrusfontein, Paardekraal, Langlaagte, Turffontein, Driefontein and Elandsfontein (Fig. 5). Two tented camps, 'Ferreira's Camp' (named for Col. Ignatius Philip Ferreira (1840-1921) who unofficially ran it) in the north part of Turffontein, and 'Natal Camp' on Doornfontein, rapidly sprang into being. In October 1886, the town of Johannesburg officially became established, centred on what had been the farm of Randjeslaagte (Fig. 5), subsequently replacing the tented encampments which had sprung up (see sketch-map of the area $c .1887$ by John Hunter McLea (1861-1941); McLea, 1909?). The discovery of coal close to the Main Reef at Boksburg (Fig. 4), in December 1887, ensured a local source of energy for the emerging mines.

By 1889, 800 stamp-mills were working at the mines established along the Main Reef (Fig. 7), producing 675-920 kg of gold monthly from some $41 \mathrm{M} \mathrm{kg}$ of ore (Sawyer, 1889; Dorsey, 1890; De Launay, 1896). Unfortunately, as workings gradually deepened below $100 \mathrm{~m}$, they began to go below the permanent water table and consequently unoxidised pyritic ore was encountered for the first time: 'No one, probably, .... would think that the red-stained, crumbling, soft pebble-beds and shales looking like a series of ordinary sedimentary deposits above, become below bluish conglomerates, schistose rock and hard quartzites' (Gibson, 1892, p. 413). Quite apart from the difficulty of extracting the gold from this much harder rock, recovery by amalgamation, used hitherto, no longer worked well, and chlorination was proving to be far too expensive to apply to low-grade ore (Anon., 1892c). Fortunately for the industry, in mid-1899 a sample of the pyritic ore from the Primrose mine was sent to the metallurgical chemist, John Stewart MacArthur (1856-1920) in Glasgow, and in April 1890 , the cyanidation process (which he had developed, financed by two physicians, William Forrest and Robert Wardrop Forrest, in 1886-8), in which the gold is dissolved out using weak potassium cyanide, then precipitated with zinc shavings (James, 1890; Hatch, 1911d; Gray and McLachlan, 1933) was successfully demonstrated at the Salisbury Battery, Johannesburg. A cyanide plant was erected there by the Cassel Co. in May and, by that September, it was extracting 78-98\% of the gold from the pyritic ore, concentrates and mine tailings (James, 1890, p. 5). By 1893, continuous treatment of the product from the stamp-mill was achieved (H. Jennings in Rickard, 1922, p. 238), and by 1895 cyanidation of the tailings was, on average, increasing the total recovery from the Witwatersrand mines by $38 \%$ (based on data in De Launay, 1896, p. 319), thus enabling profitable working, which would otherwise have been impossible, and ensuring the future of the mines. When Hatch arrived in Johannesburg in the summer of 1892, the mines were producing c. $3125 \mathrm{~kg}$ of gold per month (De Launay, 1896, Fig. 79, p. 493).

\section{Into the depths}

Although something was known of the geology in the immediate vicinity of the mines, and the earliest workers assumed that the beds formed a smooth 'basin' in which the dip gradually decreased towards 
its centre, 'the geological structure of the country is in fact highly complex, and is rendered still more difficult to unravel from its being apparently impossible to find any distinctive petrological band, available as a means of mapping the ground, or any group of fossiliferous strata, which might be used as a stratigraphical index. The difficulties of mapping the district are also increased by the fact that most of the country is covered by a deep red surface-layer, which is often many feet thick, and entirely conceals any outcrops over large areas. So far as is at present known the rocks are wholly unfossiliferous; while they are highly faulted, and in many cases sheared and overthrust' (Gibson, 1892, p. 405). These factors made it extremely difficult to determine whether the productive reefs, often separated by many kilometres, were part of the same formation or not. An editorial in the South African Mining Journal in July 1892, probably written by Gibson, pleaded for improved geological mapping to resolve such problems (Anon., 1892a), a factor recognised as equally affecting mining in the Californian and Australian goldfields (Brown, 1896).

Working 'in association with' (Anon.,1905) W.Y. Campbell, who became Vice-Chairman of Barnato's New Unified Gold Mining Co. in 1895, when the South African Trust and Finance Co. was wound up (Goldmann and Kitchin, 1896; Skinner, 1897), this was the challenge which Hatch had to meet. He began mapping around Johannesburg, and to the east of the city, with careful elucidation of the stratigraphy (Fig. 8). Curiously, the presence of gold in the banket reflected what he would have read of Posewitz's experience of Borneo where, in addition to its occurrence in quartz-veins, the goldbearing beds in the 'Diluvium' of the plains consisted of quartz sands and conglomerates (Hatch,



Fig. 8. Part of a geological map of the vicinity of Johannesberg, made by Hatch c. 1892, reproduced from Hatch and Corstorphine (1905a, fig. 25); a redrawn version of this map, without the urban detail in the vicinity of Johannesburg and extended to the south and east, appears in Hatch (1911c, pl. I).

1892c, p. 115) 'sometimes knit together by a siliceous cement into a compact mass like stone which can only be broken by use of a crowbar' (Posewitz, 1892, p. 329).

The complete absence of fossils made both determination of the age of the majority of the rocks and their correlation with the thick sedimentary sequence to the south, which was then known as the Cape System (Molengraaff, 1895), extremely difficult. Hatch (1898) concluded that the base of the succession was represented by the various granitic bodies of Archaean age, of which the largest lay immediately north of the Witwatersrand range, between Johannesburg and Krugersdorp; with a 
second [the Vredefort granite] mainly present on the Free State side of the Vaal river; and a smaller mass $15 \mathrm{mi}(24 \mathrm{~km})$ east of Heidelberg. The Cape System had been divided by the Dutch geologist, Gustaaf Adolf Frederik Molengraaf (1960-1942) into an Upper and Lower Division (Molengraaff, 1895), with the boundary at the base of the Klipriversberg Amygdaloid, but Hatch (1898, p. 77) recommended setting the division at the top of the Witwatersrand Beds, believing an unconformity to be present at that level (Table 1). These formations were, in their turn, unconformably covered by the coal measures of the Karroo System, then being mined at Vereeniging (Fig. 4) and Boksburg to supply coal to the mines, which the leading English palaeobotanist, Albert Charles Seward (18631941), determined to be of Permo-Carboniferous age, based on specimens of their copious plant remains sent to him by Hatch (Seward, 1898).

Thickness $\mathrm{ft}^{\mathrm{a}}(\mathrm{m})$

Magaliesberg \& Gatsrand Series

(quartzites, shales and volcanic flows)

Dolomite Formation

(magnesian and siliceous limestones and cherts)

Black Reef Formation

(quartzite and conglomerate)

Klipriversberg Amygdaloid

unconformity

Witwatersrand Beds

(quartzites and conglomerates, including the 'Banket' Reefs)

Hospital Hill Series

$8,000-10,000(2440-3050)$

(quartzites and ferruginous shales)

$16,000-20,000(4,880-6,100)$

$6,000-8,000(1,830-2,440)$

$20-50(6-15)$

$5,000-6,000(1,525-1,830)$

11,000-15,000 (3350-4570)

o

W

B

e

d

$\mathbf{s}$

${ }^{\text {a }}$ Hatch (1898, p. 91)

Table 1. Stratigraphic succession proposed by Hatch (1898).

In the vicinity of Johannesburg, the Hospital Hill beds formed a prominent ridge $c .1 \mathrm{mi}$ (1.6 $\mathrm{km})$ to the north of the town. Progressing southwards, into the Upper Witwatersrand Division, one then crossed the Main Reef Series of conglomerates, with the low-grade Bird Reef Series about $1 \mathrm{mi}$ $(1.6 \mathrm{~km})$ away to the south (Fig. 8) and the Kimberley Reef series $1 \mathrm{mi}(1.6 \mathrm{~km})$ still further south, all 
separated by beds of sandstone and quartzite, before entering the thick conglomerates of the Elsberg Series and the Black Reef, some $4.5 \mathrm{mi}(7.2 \mathrm{~km})$ south of Johannesburg, followed by the massive Dolomite Series. The Main Reef Series consisted of three principal reefs: the 4.5-6 m thick Main Reef itself, the northernmost; the 0.3-2 m thick Main Reef Leader immediately to the south of it, and separated from it by $0.3-2 \mathrm{~m}$; and finally, some $25 \mathrm{~m}$ southwards, the South Reef Leader, which itself consisted of two to three thin bands of conglomerate up to $1 \mathrm{~m}$ apart and, on the whole, this proved to be the richest and most consistent in its grades. The whole succession was cut by faults, occasionally with horizontal throws of up to $200 \mathrm{~m}$, and diabase dykes. Dips of the gold-bearing horizons could vary between $80^{\circ}$ and $30^{\circ}$ (Williams, 1905).

Around all this, Hatch was also beginning to work underground. Despite earlier experience when at university in Germany, he may have had this in mind when he later wrote of a hypothetical 'academic geologist' 'groping his way in a murky atmosphere but dimly illuminated by the miners lamp or the glimmer of a candle .... being asked to unravel the intricacies of a fault or to prognosticate the downward extension of an ore-body. In fact, the lavish natural indications, which at the surface attract the attention of the geologist, tend at first to elude him when he penetrates beneath it; since there exposures are few in number, and, such as they are, small; moreover, they are, as a rule, covered with dust, begrimed with soot or buried in mud. Even to overcome initial difficulties such as these is not enough: to achieve real success the work of the miner must be followed step by step, since in his progress he effaces the facts almost as soon as they are disclosed' (Hatch, 1914a, pp. xlviii-xlix).

In a company report written in 1893 (quoted in Hatch, 1922, p. 251), he concluded that the reefs being worked by the Kleinfontein, Van Ryn and Modderfontein Companies (Fig. 9), hitherto believed to be unrelated, were actually all part of the Main Reef (Fig. 10), noting that: 'The main

\section{KRUGERSDORP}

- Randfontein

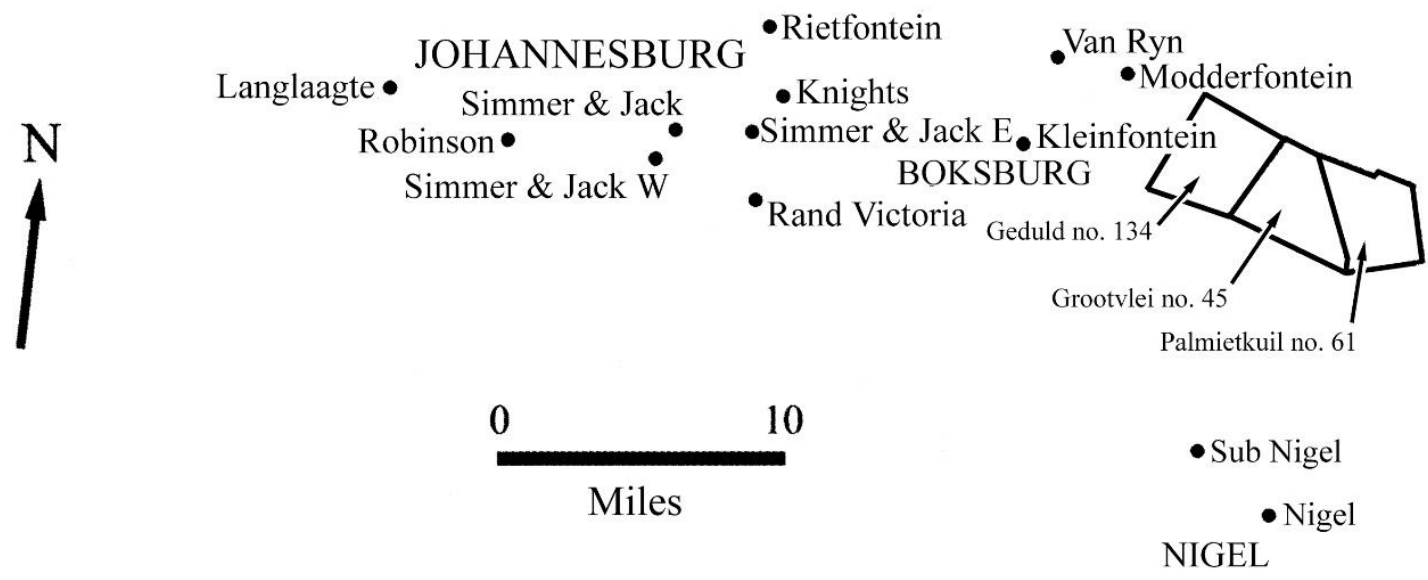

Fig. 9. Location of mines mentioned in the text in the Johannesburg district c. 1895. Town names are in upper case. The farms across which Hatch carried out his programme of borings in 1904 are also shown.

points which should guide the intending investigator are: (1) The slate footwall of the Main Reef series. (2) The presence of a series of big Reefs higher up in the order of stratification (Bird Series). (3) The presence of another group of Reefs still higher up in the succession (Kimberley Series). (4) A 
large series of coarse conglomerates at the top (Elsberg series). (5) The presence of an alternating series of quartzites and slates below the Main Reef series (Hospital Hill formation).'

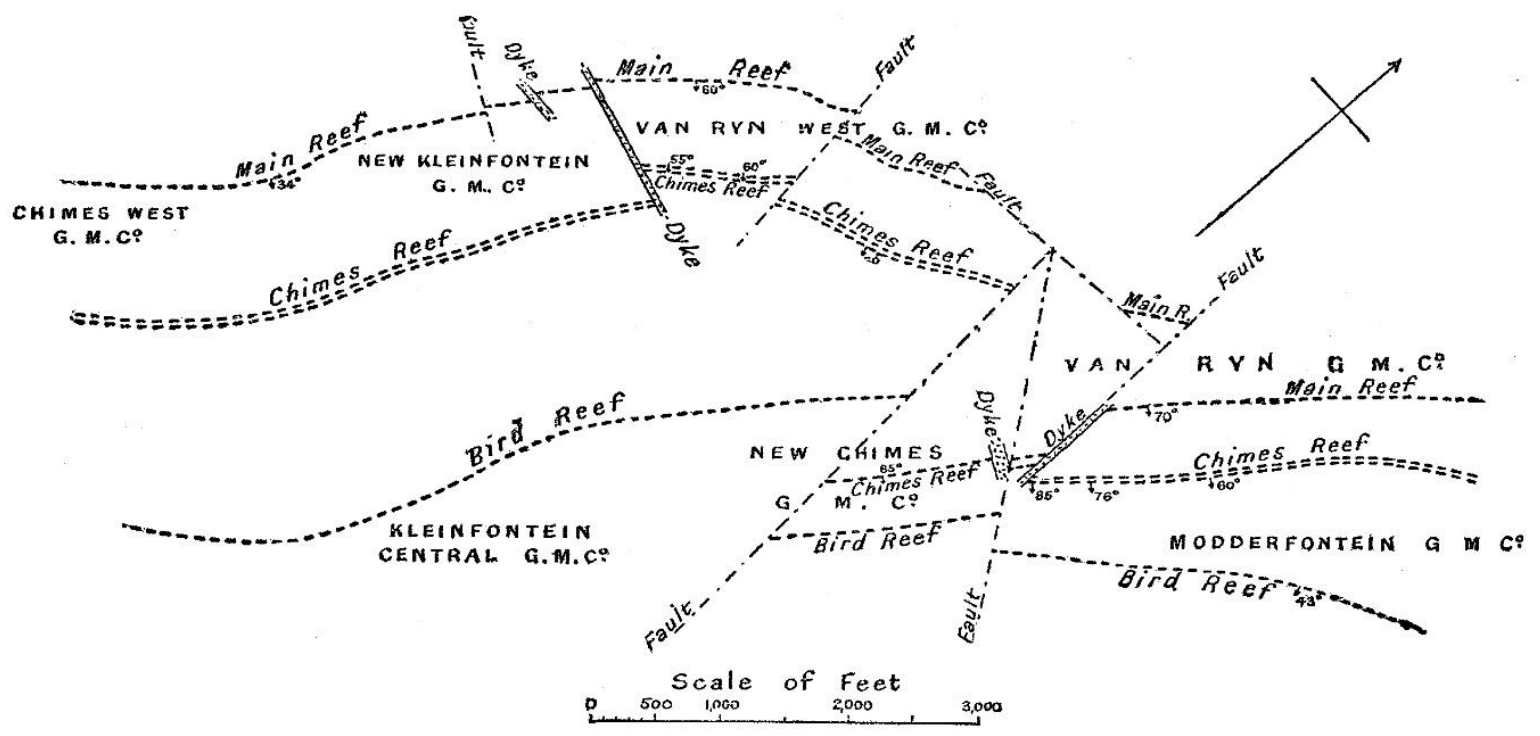

Fig. 10. Map of the reefs being worked by the Kleinfontein, Van Ryn and Modderfontein Companies, East of Johannesburg. Reproduced from Hatch (1898, fig. 1).

In 1890, the majority of claims were being worked to depths of no more than $400 \mathrm{ft}$. (122 m) but, following the Village borehole (1889) which showed the reef continued down-dip at depth (Handley, 2010, p. 102), the purchase of so-called 'deep level' claims (i.e. >1650 ft (503 m); Anon., 1937, p. 37) parallel to the line of the Main Reef, and down-dip of the best outcrop properties, was being encouraged (The Editor,1890; Anon., 1892b). Companies such as Werner, Beit \& Co. (registered 1886) had already begun to do so, and its rival, The Consolidated Gold Fields of South Africa (registered Aug. 1892), owned by Rhodes, businessman, mining magnate, politician, and founder of Rhodesia (now Zimbabwe), followed suit on the advice of an American mining expert, Hamilton Smith (1840-1900) (Anon., 1937, p. 40).

Barnato was being urged to do the same: 'Messrs. Barnato would do well in future to employ some accredited engineer of known reputation and standing ... to advise upon the working of their mines, with the object of avoiding in the future the mistakes which would at present seem inseparable from their management' (Anon., 1892d). He accordingly arranged to meet the American mining engineer, John Hays Hammond (1855-1936), who had extensive experience of gold-mining in the USA and Mexico, in London in April 1893. Barnato persuaded him to join his company as Chief Engineer. Hammond arrived with his family in Johannesburg in the autumn of 1893 (Hammond 1935) and Hatch now became his assistant. Hammond also added to his staff several American engineers, and two more English geologists who were then working in the Transvaal: John Alexander Chalmers (1865-1912) and Samuel John Truscott (1870-1950), who later wrote a textbook on the goldfield's geology and mining practice (Truscott 1898).

Unfortunately, Barnato would not be persuaded by Hammond's urging that he should sell his outcrop properties and reinvest in claims with deep-mining potential before a competitor, Alfred Beit (1853-1906), could buy up the best ground, as his existing companies were already doing extremely well financially (Jackson, 1970). After six increasingly frustrated months, Hammond resigned in April (? March) 1894 (Hammond, 1935; Anon., 1937; Jackson 1970), accepting an instant invitation from 
Rhodes to join Gold Fields as its Chief Consulting Engineer. Hatch, Chalmers and Truscott moved with him (Hammond, 1935). Hammond's team had already considered the problems of sinking shafts much deeper than hitherto, as well as possible dewatering problems. The accumulating geological evidence in the Witwatersrand was showing that rapid changes occurred in the angle of dip of the gold reefs, both at outcrop and with depth, and it was uncertain what would happen at depths much below $1000 \mathrm{ft}$ (305 m). Nevertheless, Hammond, Hatch and Chalmers were confident that as evidence from boreholes showed no sign of the grade of the reefs decreasing with depth (Anon., 1893b) and that temperatures in the mines should not exceed $32^{\circ} \mathrm{C}$ at $3300 \mathrm{ft}(1000 \mathrm{~m})$, by installing suitable mineventilation systems, deep-level mining should be both practical and economic down to depths of 5000 ft (1525 m) (Hammond, 1895; Hatch and Chalmers, 1895, chap. 5). Consequently, development of the Nigel Deep mine (Fig. 9) in the south-eastern part of the basin began (the company was registered in May 1894; Anon., 1937, p. 170). Hatch visited the Heidelberg area (Fig. 4) in 1894 and concluded that since the same stratigraphy applied as at the Nigel mine, then it too must be working the Main Reef (Hatch, 1922).

That August, at Rhodes' behest, Hammond and a team, which included Hatch and Chalmers, set out on a two month-long expedition to Rhodes' recently acquired Mashonaland and Matabeleland, Rhodesia (Fig. 2), to assess whether it was worthwhile to exploit the extensive gold reefs, which had been worked to shallow depth in ancient times but abandoned long since. On their way north from Pretoria to Bulawayo, according to Hammond (1935, p. 262) a journey of some $500 \mathrm{mi}$, but in reality more like $380 \mathrm{mi}(600 \mathrm{~km})$, by bullock-drawn waggons (Hammond, 1935, p. 262), they were joined at Bulawayo (Fig. 1) by Rhodes and the Scottish surgeon, Leander Jameson (1853-1917), who had become one of his most trusted associates (Thomas, 1996). Chalmers and Hatch (1895) concluded from their investigations, that the lodes were gold-bearing fissure-filling quartz veins in metamorphosed basement related to intrusion of granites and, while this had potential for deep mining, as a source of gold it was obviously a riskier investment than was the Transvaal. Although Hammond and Rhodes were in agreement with their view, it unfortunately subsequently caused Rhodes' stock-holders to be reluctant to invest in the new territory. Consequently, Gold Fields interests now focussed on development of deep-level properties on the Rand (Fig. 9): Robinson Deep and Simmer \& Jack (co. reg. Sep. 1894), Nigel Central (May 1895), Sub Nigel (Aug. 1895), Rand Victoria and Knights Deep (Sep. 1895), Simmer \& Jack East (Oct. 1895) and Simmer \& Jack West (Dec. 1895) (Anon., 1937).

\section{Politics intervenes}

Since 1892, the mining industry had been suffering from the policies of Transvaal's Boer government: there were duties of at least $28 \%$ on the passage of vital commodities required by the mines (e.g. timber, cement, coke, corrugated sheet- and bar- iron, candles, machinery of all types, sulphuric acid, mercury, and cyanide) over the Transvaal section of the railway line from the Cape to Johannesburg, and $10 \%$ of total expenditure of the mining companies went on the compulsory purchase of poorquality locally-manufactured dynamite, bought at exorbitant prices from a firm owned by Edward Lippert, Alfred Beit's cousin, which paid a 'royalty' to a member of the government. To make matters worse, it was argued by some, the 'Uitlander' [foreign] community (which outnumbered that of the Boers by $c .3: 1$ ) paid $90 \%$ of the taxes but policing, educational facilities and other services were poor, and they had no political representation in the government at all. Hammond was enraged by all these things (Hammond, 1935; Jackson, 1970) and believed that discontent with the Boer government was growing generally (Fitzpatrick, 1899). Writing in August 1899, Hatch appeared to agree with this view: 'The most pressing reforms required are: the expropriation of the monopolist railway, the cancellation of the dynamite monopoly, the suppression of the illicit liquor traffic, and last, but not 
least, a voice for the Uitlander in the expenditure of the State revenues' (Hatch, 1899, p. 817). By the summer of 1895, a 'Reform Movement' had begun. However, as pointed out by Nutting (1970, p. 314), 'while some of the more irresponsible .... Uitlanders might have threatened revolution .... most of them were doing far too well to risk a collision with the Boer authorities.'

As a result of his position as Hammond's assistant, Hatch must have been well-aware that 'the game was afoot' and with the impending birth of another child providing a convenient excuse, the family returned to England in June 1895, and his third son, Maurice, was born in August. Following his election as a Member in the Mining Division of the IMM, on 16th September, Hatch gave a paper entitled: On the Auriferous Conglomerate of the Witwatersrand at the meeting of the British Association for the Advancement of Science in Ipswich that September (Hatch, 1896) then left for Spain to undertake an investigation in the Huelva mining district (Hatch, 1911e).

His definitive book with Chalmers, Gold Mines of the Rand, published in the autumn of 1895, was well-received. Despite minor criticism of the authors' stratigraphical interpretation, one reviewer (clearly having Hatch in mind) pleaded 'that a geologist, who is both a good stratigraphist and a petrologist, will attempt to unravel the geology of the country' (Anon., 1895), but he was already addressing this issue.

By December 1895, in the Transvaal, a Reform Committee, 'a group of hard-headed, successful, conservative men of affairs' (Hammond, 1935, p. 319), which included Hammond, had been formed, with the stated intention of establishing a new government by force if a final appeal for reason to the Boer government (to be made on 6 January 1896) failed: With arms and supplies largely financed through Gold Fields, it was intended that 1500 mounted armed men, under Jameson, would depart from Pitsani, near the western Transvaal border, march $185 \mathrm{mi}$ (298 km) to Pretoria (Fig. 2), seize the fort and its supplies and then transport them by rail to Johannesburg; meanwhile 9,000 armed men would seize control in Johannesburg. Unfortunately, unwilling to listen to advice, Jameson left prematurely on 29 December 1895, with a force of 520 armed horsemen (of whom 400 were Bechuanaland police troopers, supplied by Rhodes' Chartered Company), aiming for Johannesburg. On 2 January 1896, he was met $12.5 \mathrm{mi}(20 \mathrm{~km})$ west of Johannesburg by a force of 1200 well-armed Boers and forced to surrender. By January 10th, Hammond and the other leaders of the Reform Committee had been arrested, on grounds of having committed treason against the ZAR, and taken to Pretoria. Put on trial in April 1896 and imprisoned under sentence of death, as a result of a political compromise with the British Government they were eventually deported to England that July (Fitzpatrick, 1899; Nutting, 1970; Packenham, 1979). In the aftermath, mines began to close down and there was a general economic down-turn, but Hammond, now based in London, continued to act as a Consulting Engineer for Gold Fields. 
By June 1896, the Hatch family had returned to Johannesburg, and he resumed his geological work with Gold Fields, but 'the difficulties of geological mapping in a sparsely-inhabited country, and where the inhabitants since the Jameson raid have not been particularly disposed to welcome the Uitlander, may be easily imagined' (Hatch, 1898, p. 73). Nevertheless, in the following year he managed to complete the topographical and geological maps of $c .5,040 \mathrm{mi}^{2}\left(13,000 \mathrm{~km}^{2}\right)$ of the southern Transvaal, at a scale of $4 \mathrm{mi}: 1$ in $(1: 253,440)$, which he had begun some five years previously (Hatch, 1897a, 1897b). Figure 11 shows a much reduced monochrome version of the map published in Hatch (1898).



Fig. 11. Geological map of the southern Transvaal. Reproduced (at much reduced size) from Hatch (1898, pl. VI).

The family returned to England for the birth of their daughter, Olive, that October and, in November, he gave a paper on his work at the Geological Society, London (Hatch, 1897c). He suggested that the auriferous Nigel conglomerates formed the southern edge of a syncline, and that it ought to be possible, by putting down deep boreholes, to find the position of the eastern rim, which was hidden beneath the unconformably-overlying Dolomite Series and Ecca Beds (Hatch, 1898). However, problems with the dynamite monopoly and duties on other commodities continued, and a $5 \%$ tax on mining company profits was imposed (Hatch, 1899). The conviction among the Uitlanders that an Anglo-Boer war was inevitable began to strengthen. By late August 1898, reinforcements of 10,000 British troops had arrived in Natal and continued to grow. In the Rand, managers, professional men, and their families began to leave. By the 5th September, some 60,000 refugees had left, the mines were closing down and the native workforce largely dispersed (Nutting, 1970; Packenham, 1979). Hatch and his family had joined the exodus for England. On the 11 October 1899, the Boer War began. 
In the latter part of 1898 and 1899, Hatch worked as a consultant on gold and other deposits in Montana, Arizona, New Jersey and California, USA, and the gold-mining areas at Nelson and Sandon, Kootenay Lake, south-eastern British Columbia, Canada (many of which are discussed in Hatch, 1929). From March 1900, he was in India, attached to the staff of the Indian Geological Survey for a year (Anon., 1901), to report on the goldfields at the request of Indian Government, visiting Devala, Calcutta, Bangalore and, particularly, Wainad and Kolar (Hatch, 1902a, 1902b), but that October, he also visited several gold prospects in Eritrea, of which the most favourable was at Schiumagalle, near Addi Apsulus (Hatch, 1902c; quoted in Jelenc, 1966, pp. 137, 192-3, 196; Società Eritrea per le Miniere d'Oro, 1902b; Zaccaria, 2005). He returned to England in March 1901.

\section{The post-war years}

On 26th March 1902, Rhodes died of heart failure and the Boer War ended on 31st March (for discussion, see: Wilson, 1900; Nutting, 1970; Packenham, 1979). It had been a disastrous time for the goldfields. As the gold mines and railway became active once again, there was an increasing, and highly competitive, demand for coal. Hatch (accompanied by his wife and daughter, leaving his three sons at Oundle boarding school in England) returned to Parktown (north of the centre of Johannesburg), where he took up a new appointment as Chief Consulting Engineer to the firm of Lewis \& Marks (originally founded by two Lithuanian-born South African entrepreneurs, Samuel Marks (1843-1920), and his cousin, Isaac Lewis (1849-1927) in the Kimberley diamond fields), with a brief to establish an engineering department for the partnership.

Hatch now spent four days a week at Vereeniging, the town where the Peace Conference took place at the end of the Boer War, and where Lewis \& Marks' subsidiary, the Vereeniging Estates Co. (reg. 1897) ran the second-most productive coal mine in the Transvaal, with seams between 3 and $6 \mathrm{~m}$ thick within $60 \mathrm{~m}$ of the surface and 'mining is easy' (Moseley, 1906). In January 1903, Joseph Chamberlain, Secretary of the Colonies, visited Johannesburg, and Hatch was one of a committee of 15 mining engineers who compiled a descriptive and statistical review of the gold mining industry of the Witwatersrand for his benefit which 'went thoroughly into the past history of the goldfield; the yields, working costs, and statistics of past workings; the probable number of stamps that might be required in the future; the wages, living expenses, and relative proportion of natives and white men to bring about the best results in the future' (H. Jennings, quoted in Rickard, 1922, p. 247). Later that year, the second edition of Hatch's Geological Map of the Transvaal (1903a, 1903b) was published, and he was appointed to the Transvaal Technical Education Commission (Technical Education Commission, 1903). On the basis of their recommendations, students were transferred from the original School of Mines in Kimberley to the School of Mines in Johannesburg. He was also appointed, together with the Scottish geologist, Corstorphine, as a joint Honorary Secretary, Treasurer and Editor of the GSSA for 1903-04. Corstorphine had been Consulting Geologist to Gold Fields in Johannesburg since 1902, having previously been the first holder of the Chair of Mines and Technology at the South African College, Cape Town (1895-96) and Director of the newlyestablished the Geological Survey of the Cape of Good Hope (1896-1902). His experience of the geology of the Cape complimented Hatch's in the Transvaal. 
Apart from Hatch's own work on the Witwatersrand succession (Hatch, 1903c-e), in 1903, he and Corstorphine began working together on the first textbook on The Geology of South Africa (Hatch and Corstorphine, 1905a), establishing a definitive stratigraphy (Fig. 12) and also studied the stratigraphy and petrology of the shales and auriferous conglomerates of the Witwatersrand succession (Hatch and Corstorphine, $1904 \mathrm{a}$, 1904b; 1905b; Williams, EUROPEAN EQUIVALENTS. 1905). They concluded that while the quartz and quartzite fragments in the conglomerate were evidently water-borne, there was no definitive evidence that the occasional rounded 'buckshot' pyrite grains and 'pebbles' found among the pyrite crystals showed any signs of 'superficial weathering' and were probably accretionary. The Oxford mineralogist, Henry Alexander Miers (18581942), confirmed for them that the small black spots associated with the gold in the 'Carbon Leader' of the Reitfontein and Randfontein mines (Fig. 9), and at Buffelsdoorn, north of Klerksdorp (Fig. 4) was, indeed, carbon (Hatch and Corstorphine, 1904b, f.n. 141), as Hatch (1903c, 1903e) had suspected. Hatch and Corstorphine also established that extensive silicification of the conglomerates post-dated much of the pyrite, and that the gold often cemented rounded pyrite particles. They concluded that the gold and most, if not all, of the pyrites must therefore have been transported in solution and crystallised in the matrix of the conglomerate. They argued against its origin as a modified placer-deposit containing gold (a view popular with some, e.g. Gregory, 1907), and went on to suggest that precipitation of the gold in particular beds might have taken place as a result of the presence of some unknown reducing agent connected with the presence of pyrites and

\section{Superficial Deposits.}

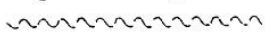

Cretaceous
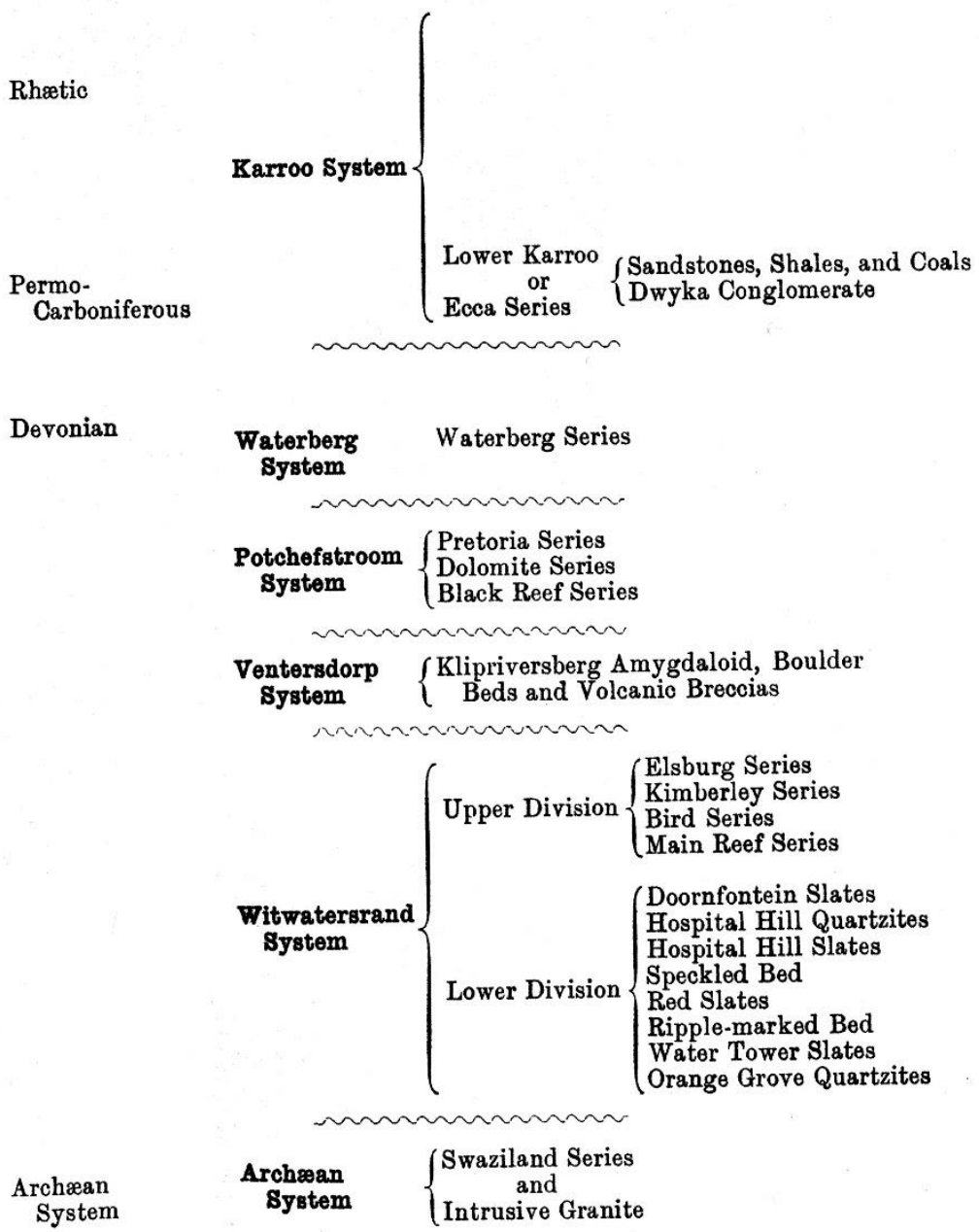

Fig. 12. Stratigraphy of the Transvaal. Reproduced from Hatch \& Corstorphine (1905a, pl. I). 
that the 'carbonaceous matter' might have played 'a greater role in the precipitation of the gold than is usually thought' (Hatch and Corstorphine, 1904a, p. 145).

At Klipfontein farm, $4 \mathrm{mi}(6.4 \mathrm{~km})$ east of Modderfontein (Fig. 9) the south-dipping goldbearing conglomerates of the Witwatersrand Series disappeared underneath the cover of the Dolomite and Ecca Beds, and were known to re-emerge, with dip reversed, at Marievale farm, $2 \mathrm{mi}(3.2 \mathrm{~km})$ east of Nigel (Fig. 9) in the Heidelberg district. Hatch had previously suggested (Hatch and Chalmers, 1895; Hatch, 1898) that it ought to be possible to trace the connection between the Nigel conglomerates and those on the Rand. Now his opportunity to do so arrived, as Lewis \& Marks also held mining interests (through East Rand Mining Estates) in two farms in the East Rand: Grootvlei No. 45 and Palmietkuil No. 61 (Fig. 9; the numbers correspond to those of Jeppe, 1899) which lay near the supposed centre of the syncline and southeast of the farm Geduld No. 134, where three boreholes drilled by Goertz \& Co. in 1897 had encountered the Van Ryn Reef at depths of 1388-2136 $\mathrm{ft}(423-651 \mathrm{~m})$. He initiated a programme of boreholes, along a $10 \mathrm{mi}(16 \mathrm{~km}) \mathrm{NW}-\mathrm{SE}$ traverse across where he believed the axis of the basin probably lay, to try to locate the gold-bearing reefs at depth. The first four boreholes, on Palmietkuil, were unsuccessful (one was cut-out by a dyke; another 'abandoned by the Contractors in the Dolomite') but the fifth, on the western boundary of Grootvlei, struck what he recognised to be the Nigel-Van Ryn (Main) Reef, at a depth of $3412 \mathrm{ft}$ (1040 m). A further three boreholes were equally successful. The drilling campaign was completed in 1904, with the intersected reefs yielding good gold values. As a result of this evidence, Hatch and the American mining engineer, Thomas Haight Leggett (1859- fl. 1925) confidently suggested in 1902 (Leggett and Hatch, 1904) that the reefs would be found to continue below $6000 \mathrm{ft}(1830 \mathrm{~m})$ and could be mined at that depth, a claim greeted with scepticism by some at the time (Leggett and Hatch, 1904, discussion), but this depth was eventually reached by the Deelkraal No. 1 shaft in 1977 and, today, the Western Deeps South Shaft is operating at 12,795 ft (3900 m) (Handley, 2010, pp. 102-103).

Using additional data from earlier borings, Hatch was able to construct a subsurface contour map to show the probable depths at which the Main Reef (hidden beneath a cover of up to $300 \mathrm{~m}$ of the Dolomite Series) would be encountered in the East Rand (Fig. 13; Hatch, 1904a, 1904b). However, most unfortunately, it soon became apparent that the presence of previously unknown aquifers in the Dolomite Series would pose major problems for exploitation of the reef, although fortuitously solving the problem of Johannesburg's water-supply (for example, in 1910, sinking of the Pullinger shaft in the West Wits area had to be abandoned at a depth of only $100 \mathrm{ft}(30 \mathrm{~m})$, owing to an uncontrollable influx of up to 5 million gallons of water per day). Because of this, opening-up of the reserves which Hatch's work had indicated were potentially accessible did not prove possible until 1911. 




Fig. 13. Subsurface contour map of the expected depth of the Main Reef in the East Rand. The Main Reef and its correlates, the van Ryn and Nigel reefs, are as a solid black line. The margin of the covering by the Dolomite Series and Ecca Series is shown as a hachured band. Borehole locations are also shown. Reproduced (at much reduced size) from Hatch (1904a, pl. XVI); farm boundaries and names have been omitted for clarity.

During 1904, Hatch had become sole Honorary Secretary, Treasurer and Editor of the GSSA, and his fourth son, Gilbert, was born in Johannesburg that November. He and Corstorphine had also formed the 'Museum Committee' of the Society, and oversaw the removal of the Society's collection of specimens from the Chamber of Mines building, where it had been housed for many years, to the General Mining and Finance Corporation Building in Marshall Square, Johannesburg. On 30th January 1905, he was elected President of the GSSA, with Corstorphine as his Honorary Secretary. Five days previously, a 3,025 carats (620 g) blue-white diamond had been found in yellow ground at the Premier Mine, near Pretoria, and it was more than three times the weight of the largest diamond hitherto known. Although actually found by 'Mr. Wells, the Surface manager' it was named after T.M. Cullinan, the Chairman of the Premier Company. Hatch and Corstorphine were invited to examine it. When Hatch returned to England with his family in February 1905, in order to finalise the production of their textbook, he 'exhibited lantern slides' of photographs of the diamond (Fig. 14) at a meeting of the Geological Society of London on 8th March and at a meeting of the Mineralogical Society on 15th March (Hatch, 1905a, 1905b). Stereoscopic photographs were also shown at a meeting of GSSA in Johannesburg, on 13th March, and their detailed description (Hatch and Corstorphine, 1905c, 1905d; 1906) was read to the meeting. Hatch subsequently became interested in the controversy regarding the nature of the diamond-bearing kimberlite pipes and dykes of the Transvaal. In a review article (Hatch, 1908) he noted that Corstorphine favoured the minority view 
that the diamonds were 'derived from a deepseated source' as many, including the Cullinan, showed signs of fracturing, and the occurrence of isolated broken fragments was common.

The publication of their book, The Geology of South Africa (Hatch and Corstorphine, 1905a), for which Hatch completed the Foreword in London that June, was well received (W.G., 1905). Revised in 1909, it would remain 'the only

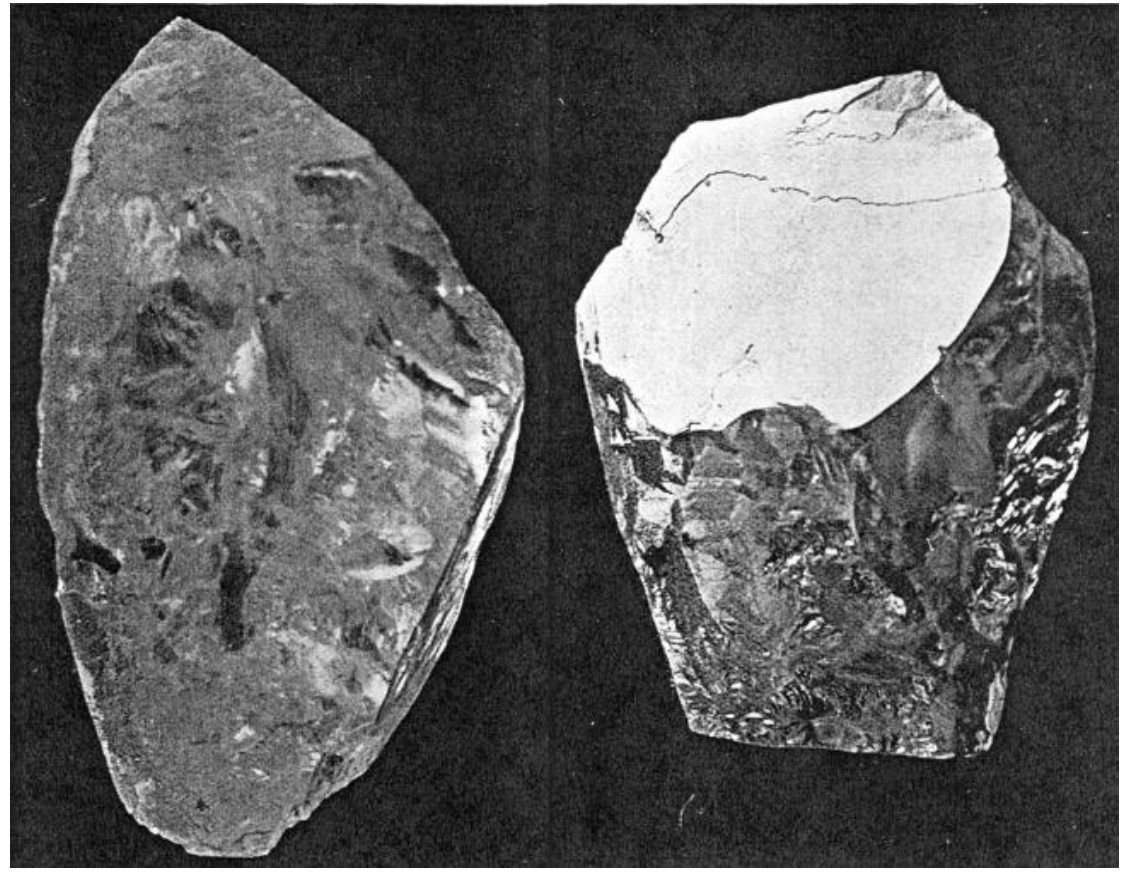

Fig. 14. Two views of the Cullinan diamond (c. actual size) photographed by E.H.V. Melvill. Reproduced from Hatch (1905b, pl. VII).

comprehensive book on the subject for the next 20 years' (Rogers, 1937, p. 129).

Hatch returned to Johannesburg in time to participate in the 57th Meeting of the BAAS, held in Cape Town and Johannesburg between 16 August and 1 September, at which he gave two papers (Hatch, 1905c, 1905d) and led a field trip to the Vereeniging Coalfield (Hatch, 1905e). During the course of the meeting, it became evident that 'the separation of southern Africa into six political regions (Cape Colony, the Transvaal, Orangia, Natal, Rhodesia, and German South West Africa) had led to 'overlapping systems of [stratigraphic] nomenclature which are confusing to students in other countries and may give rise to future difficulty in South Africa' (Gregory, 1911, p. 123). A BAAS Committee, under the chairmanship of John Gregory (1864-1932), Professor of Geology at Glasgow University (who also had his own views on the Goldfield: Gregory, 1907), was consequently 'appointed to investigate and report on the Correlation and Age of South African Strata and on the Question of a Uniform Stratigraphical Nomenclature' (Gregory, 1911, p. 123; Hatch, 1911a). The Transvaal was represented on this committee by Hatch and Corstorphine; Herbert Kynaston (18681915), Director of the Geological Survey of the Transvaal since 1903; and R.B. Young, Professor of Geology and Mineralogy at the Transvaal University College, Johannesburg, who was also particularly interested in the banket (Young, 1917). Hatch was also made Secretary of a second Committee, under the Chairmanship of George Lamplugh (1859-1926) of H.M. Geological Survey of Great Britain: 'appointed to determine the precise Significance of Topographical and Geological Terms used locally in South Africa' (Hatch, 1909a, p. 291; 1910a, 1911b). When Hatch gave his valedictory Presidential Address to the GSSA (Hatch, 1906, 1907a), on 29th January 1906, on the evolution and stratigraphic succession of the Transvaal, it proved controversial as, apart from elucidating the stratigraphic succession, he accused Kynaston and his Geological Survey of neglecting the geology of the Rand in favour of outside districts. Somehow, he also found the time to work with the Scottish mining engineer Edwin James Vallentine (1877?-1951) to compile Mining Tables, a compendium 'of formulae, constants and other data useful to them in the exercise of their profession, which are not always to be found in text-books' (Hatch and Vallentine, 1907, p. i). The information 
contained ranged from the weights and measures used in various countries, to means of surveying mining properties, valuation of ore-reserves, or expressing copper prices.

\section{Return to England}

Possibly prompted by a severe regional economic recession which caused the collapse of the coal industry (Mendelsohn, 1991), and with his term as President of the GSSA ended (to be succeeded by Corstorphine), Hatch returned to England in February 1906, and established himself as a Consulting Mining Engineer in London. Soon he was off again, examining mines in the Siberian goldfields (Hatch, 1907b).

However, his return to England was not the end of his connection with the geology of the Transvaal. Quite apart from his membership of the BAAS working parties, he represented the Republic of South Africa at the Centenary meeting of the Geological Society, London, in 1907, and subsequently returned to South Africa, at the request of the Government of Natal, to undertake an appraisal of metalliferous mines in Natal and Zululand during March-November 1909 (Hatch, 1910b). Hatch's conclusions were, broadly: that there were no deposits of commercial value of either precious- or base-metals; that coal was the only commodity worthy of attention; that a mechanism for proper retention of plans of both surface and underground workings was required; and that there "was a crying need' for the re-establishment of the state's Geological Survey, which had been set up in 1898 and closed down in 1905. His findings (Hatch, 1910b, 1911c) were received with considerable disappointment by both the mining community (Anon., 1910) and the Government of Natal, especially as they discouraged further investment in the colony. When a draft report of his conclusions was tabled for the Government's information at the end of November 1909, rumours must have circulated, and a commentator acidly noted that 'to ascertain, investigate, and report upon the mining potentialities of a country topographically difficult, with a scanty mining literature and a partial and unsatisfactory Geological Survey, is a task requiring a much longer period than it fell to the lot of Dr. Hatch to have at his disposal' (Anon., 1910). At the behest of the Natal Government, he also made a collection of 251 rock and 330 ore specimens for the Pietermaritzburg [later, Natal] Museum (Hatch, 1909b; Dr. J.G.H. Londt, pers. comm., 1997), and also presented similar collections to the Imperial Institute, South Kensington, London, and the Department of Mineralogy and Petrology, Cambridge.

From July 1910 until June 1913, Hatch and his family were based in Cambridge where, as a Member of Christ's College, he lectured on economic geology. Towards the end of 1910, and again at the close of 1911, with the aid of the Mineralogy Department at Cambridge, Hatch examined diamonds, gold, and heavy-minerals in concentrates brought to him by the Liberian Development Co., to whom he was a technical advisor, from the Jiblong and Bor rivers, Liberia (Hatch, 1912a). He also completed the 4th edition of his Mineralogy textbook (Hatch, 1912b) which had been previously reprinted, but was only now revised, and worked with the English petrologist, Robert Heron Rastall (1871-1950), Demonstrator of Geology in the University of Cambridge. Their collaboration led to a petrological study of the Port Shepstone marble, Natal (Hatch and Rastall, 1910), and the first English textbook on sedimentary petrology, which embraced 'not only the loose detrital accumulations, but also their derivatives by cementation, metasomatism and other forms of metamorphism' (Hatch and Rastall, 1913, p. vi). Together with James Romanes (b. 1884), Rastall also contributed an appendix on the recognition of minerals as seen in thin-section to a new edition of Hatch's (1909c) textbook on petrology of the igneous rocks. 
In an invited lecture to The Institution of Civil Engineers, London, on The Past, Present and Future of the Gold-mining Industry of the Witwatersrand, Transvaal (Hatch, 1911d), he reviewed the history of the Goldfield and its mining technology, and updated a previous estimate (Leggett and Hatch, 1904) of the gold-producing potential of the basin. Although there was some uncertainty about the figures as, at that time there were concerns that the ore-grade of the reefs might begin to diminish with depth, assuming that the reefs could be exploited to a depth of $6000 \mathrm{ft}(1830 \mathrm{~m})$, he foresaw a minimum of 35 years life for the Goldfield with a yield of at least $£ 1406 \mathrm{M}$. Over the next few years he published several more papers on the reefs (Hatch, 1911f; 1913a, 1913b; 1914b), in some of which he engaged in a somewhat tetchy exchange of views with his one-time assistant (in 1903/04), Cuthbert Baring Horwood (1877-1960), over priority of their ideas on the theories surrounding the gold-pyrite-carbon association in the banket (Hatch, 1913a, 1914b; Horwood, 1917). His last contribution to the subject was a retrospective article on his own work on the Rand (Hatch, 1922).

Hatch visited the Urals in 1912. On 13th September 1913, he was elected President of the IMM, but visited Canada in late February 1914, returning to give his Presidential Address on 26 March. It was principally a survey of theories of ore generation (Hatch, 1914a), but his address was remembered for doing 'more for the cause of mining geology in defining its scope and importance as an integral part in the science of mining engineering than any other of its supporters' (TrewarthaJones, 1915).

On 3 August 1914, Britain entered the First World War. Iron and steel were required for the production of goods for the armed forces which ranged from the provision of 'entrenching tools, soup-cans, mess-tins, saddlery, bits and spurs' to shell cases (Hatch, 1919a, p. 1). The British steelmaking industry had long relied on importation of hematite and manganiferous iron-ores from Spain and the Mediterranean. With the outbreak of war, the threat of German submarine activity reduced the ship-tonnage available, causing a six-fold increase in the cost of imported ore, and at one point threatened to cut off the supply altogether. By February 1917, it was realised by the British government that the development of domestic sources of supply was a matter of urgency (Hatch, 1919a, pp. 69-77). Although Hatch had acted in an advisory role from October 1914, in March 1917 he joined the mining engineer, Frank Merricks (1860-1936), Consulting Engineer to the Ministry of Munitions from 1915, and was now placed in charge of Home Iron Ore and Limestone Development Section of the Iron and Steel Production Department of the Ministry. Their group's work identified large quantities of suitable phosphoric ironstone in the Jurassic rocks of the Midlands, hematite from Cumberland, as well as manganese ores from North Wales, and enabled supplies of Britishsourced iron-ores to be maintained at pre-war levels. Steel production rose from 7.8 Mt in 1914 to $13 \mathrm{Mt}$ in 1917; additional supplies were shipped in, when possible, from Spain, Sweden and France (Hatch, 1918a, 1918b; 1919a, 1919b, 1919c; 1920a, 1920b).

A revised edition of Mineralogy was published in 1916. Following the Armistice (11 Nov 1918), Hatch became a member of a Commission to examine the condition of the iron and steel works in the occupied areas of Germany, Belgium and France; and was also appointed Director of the Mineral Resources Development Branch of the Board of Trade (1919-20) and a member of the Governing Body of the Imperial Mineral Resources Bureau (1919-25). In 1920, the Mineral Resources Development department was wound up, having completed its work and he was appointed O.B.E. (Fig. 15) for his services to the

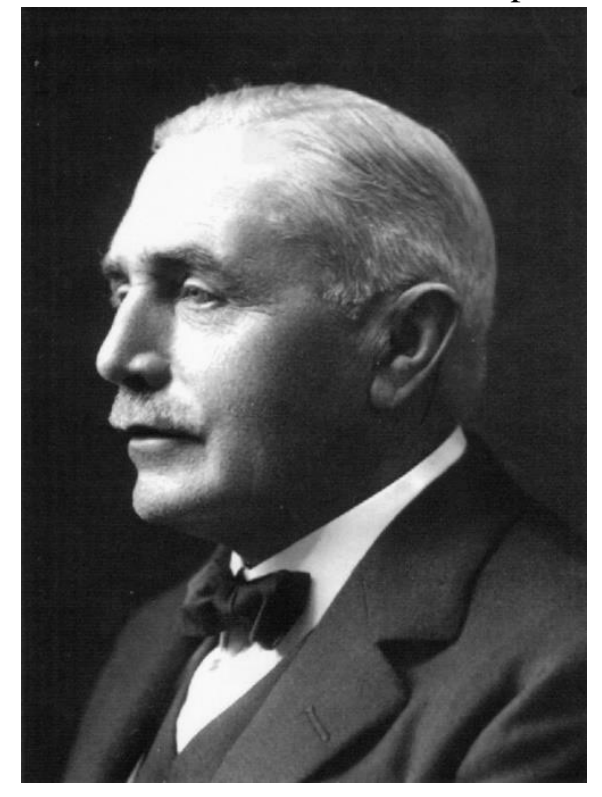

Fig. 15. Frederick Hatch c. 1914-20 (courtesy of Mrs. J. McLachlan). 
Board of Trade and Ministry of Munitions, although he continued to retain an honorary role (1921-31) as Technical Advisor to the Mines Department on questions relating to the metalliferous mining industry (Anon., 1921; Hatch, 1921).

He also served on the Committee on British Petrographic Nomenclature (1920-21), chaired by Professor William Watts (1860-1947), which was established by the Geological Society and Mineralogical Society to look into issues of standardisation of terminology of rock names (Committee on British Petrographic Nomenclature 1921); was appointed, in 1921, to the planning Committee of the Minerals Section for the forthcoming 1924-25 British Empire Exhibition; and served on the Council of Geological Society (1921-25) and on the Governing Board of the Imperial Institute (19271932). However, by 1929, when his textbook, An Introduction to the Study of Ore-Deposits, based on his Cambridge lectures, eventually appeared, his health was beginning to fail, and he resigned (with a surprisingly terse exchange of letters) from the Council of the IMM in 1930. Nevertheless, a sixth revision of his Mineralogy was published in 1931. Following an operation for an enlarged prostate, he died of bronco-pneumonia, aged 68, at his apartment: D3, The Albany, Piccadilly, London (which is almost adjacent to the Geological Society premises at Burlington House, Piccadilly) on 22 Sept 1932.

A great enthusiast for the opera, especially Wagner, and a collector of landscape paintings and antiques, he was seen by his professional colleagues as a 'painstaking, studious, highly-cultured scientist' (Trewartha-Jones, 1915) and a 'man of high attainments' (R.H.R., 1932). The quality most admired by his friends in later life, whether it was in the Athenaeum Club in London, or in the Senior Common Room at Cambridge, was that 'a scholar by up-bringing and temperament, he always retained a scholar's intellectual integrity and intolerance of sham' (unpublished draft funeral address, possibly by Rastall, Mrs. P. Soave, pers. comm.). His name is commemorated in the mineral hatchite

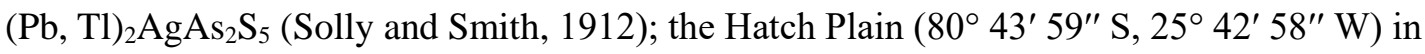
Antarctica, named by the UK Antarctic Place-Names Committee in 1971 (Hattersley-Smith, 1977); and, as mentioned in the Introduction, he is one of the 'Pioneers of Witwatersrand geology' featured on the Geological Society of South Africa's postcard.

However, so far as his family were concerned, he was, as his daughter Olive (1897-1976) described him, 'a tyrant,' an autocratic bully (no-one was allowed to leave the house, even to post a letter, when he was 'at home'), and financially mean to the point that, in later life, his wife had to breed Persian cats in order to achieve a modest income of her own (Mrs. J. McLachlan, pers. comm.). Consequently, it often came as a relief to his family when he was away undertaking consultancy or doing geology in the field. Like many families, they experienced personal tragedy in the war years: two sons, Philip (1892-1916) and Lawrence (1893-1915), were killed in action and he became estranged from his third, Maurice (b. 1895, fl. 1958), on his also joining the army in 1915 and marrying their French maid the following year, both acts against the expressed wishes of his parents. In March 1921, his wife died of Spanish influenza and he subsequently married Amie Pool (b. 1873) in 1923. Although he did not divorce her, they appear to have lived apart from c. 1927. His youngest son, Peter (1904-1987) eventually also became a mining geologist, and his daughter, who looked after Peter following their mother's death 'escaped' to become a teacher in Paris and married in 1931.

\section{Later work}

No actual sedimentological studies were carried out on the Witwatersrand succession until the 1920s, and the origin of the gold still remains controversial today, see Pretorius (1975) and Boyle (1987) for useful surveys of early work: While some workers favour a modified placer origin (Frimmel, 1996, 1997; Hayward et al., 2005), an alternative view is a hydrothermal replacement model, with the original source of the gold in mafic crustal rocks beneath the Witwatersrand Supergroup, and the 
mineralising process linked to the tectonic evolution of the basin. It has been suggested that transport of gold into the rocks which now form the Witwatersrand Supergroup occurred during metamorphism (Phillips et al.,1989; Phillips and Law, 1994; Phillips et al., 1997), which has been related to the Vredefort Impact Event (Therriault et al., 1997, Hayward et al., 2005). The gold precipitation has been linked to reaction with the carbon- and iron-bearing rocks, associated with widespread alteration by fluids channelled by structures, unconformities and bedding.

Further editions of Hatch's petrological textbooks continued to be produced posthumously: As mentioned in the Introduction, that on igneous rocks (1909c) which he had further revised in 1910, 1914 and 1926, was entirely revised by Alfred and Maurice Wells in 1926, 1949 and 1961. Hatch and Rastall's (1913) book on sedimentary petrology was reprinted in 1923 and subsequently underwent major revisions by Maurice Black (1904-1973) (Hatch et al., 1938), and John Trevor Greensmith (b. 1929) (Hatch et al., 1965) who, following a further revised edition (Greensmith et al., 1971), was eventually asked by the publishers to continue it in his own name only (Greensmith, 1978), which he revised in 1989, 'by which time there was little of the original thoughts of Rastall and Hatch remaining in the book apart from placers and beach concentrates' (Greensmith, pers. comm.).

\section{Acknowledgements}

I thank Mrs J. McLachlan and the late Mrs. P. Zouave (Hatch's grand-daughters) for their information and giving me access to family documents and photographs (unfortunately, virtually none of his personal, or work-related, papers now exist); and Dr. T. Becker (Archiv der Rheinischen FriedrichWilhelms-Universität Bonn), Dr. J.T. Greensmith (Queen Mary College, University of London), Dr. J.G.H. Londt (Natal Museum); Prof. G.T. Martin (Christ's College, Cambridge); M. McGarr (Institute of Mining and Metallurgy, London); Dr. G. McKenna (British Geological Survey); Dr. D Simons (Department of Earth Sciences, University of Cambridge); Dr. J.C. Walworth (University of London Library); and Ms. W. Cawthorne and her colleagues (Geological Society of London Library) for their help with information. I am also particularly grateful to Prof. Carl R. Anhaeusser (University of Witwatersrand) for his meticulous, and very helpful, referee's comments.

\section{References}

N. B. This is not intended to be an exhaustive bibliography of all of Hatch's publications (e.g. many Discussions are omitted), nor of later studies by others of Witwatersrand geology.

Anhaeusser, C.R. (Ed.). 1997. A Century of Geological Endeavour in Southern Africa. The Geological Society of South Africa, Johannesburg. 587 pp.

Anon. 1892a. Geological Survey of the Witwatersrand. The South African Mining Journal and Financial News 1 (no. 43), 752.

Anon. 1892b. Deep Level Probabilities. The South African Mining Journal and Financial News 1 (no. 46), 808-809.

Anon.1892c. The cyanide process in America. The South African Mining Journal and Financial News 1 (no. 52), 908.

Anon. 1892d. [Untitled]. South African Mining Journal 1 (no. 46), 821. 
Anon. 1893a. Annual Report of the Director-General of the Geological Survey of the United Kingdom the Museum of Practical Geology and the Government School of Mines and Science applied to the Arts for 1892. Appendix E. pp. 246-248.

Anon. 1893b. The Rand Mines. Result of Diamond Drill Boring. Gold Struck at Depth of 2400 feet. Thames Star, 24 (issue 7499, 16 August 1893), pp. 3-4.

Anon. 1895. The Gold Mines of the Rand [review]. Geological Magazine (Decade 4) 2, 571-573.

Anon. 1901. Notices of Memoirs. Geological Magazine (Decade 4), 8, 268-269.

Anon. 1905. Dr. Frederick Henry Hatch. In: Men of the Times. Pioneers of the Transvaal and Glimpses of South Africa. The Transvaal Publishing Company, Johannesburg, p. 188.

Anon. 1910. Natal. The Mining Journal 88 (no. 3892), 397.

Anon. 1921. [Editorial Note]. Geological Magazine 58, 13.

Anon. 1937. "The Gold Fields" 1887-1937. The Consolidated Gold Fields of South Africa Ltd., London, $185 \mathrm{pp}$.

Antrobus, E.S.A. 1986. Preamble. In: Antrobus, E.S.A. (Ed.), Witwatersrand Gold - 100 Years. A review of the discovery and development of the Witwatersrand Goldfield as seen from the geological viewpoint. The Geological Society of South Africa, Johannesburg, pp. 1-6.

Bailey, E.B. 1952. The Geological Survey of Great Britain. Murby, London, 278 pp.

Beach, H.P. 1906. A Geography and Atlas of Protestant Missions. Student Volunteer Movement for Foreign Missions, New York [v.2, Atlas].

Boyle, R.W. 1987. Gold. History and Genesis of Deposits. Van Nostrand Reinhold, New York, 676 pp.

Brown, N. 1896. The necessity for competent geological surveys of gold mines. Proceedings of the Geologists Association, 14, 212-215.

Chalmers, J.A., Hatch, F.H. 1895. Notes on the Geology of Mashonaland and Matabeleland. Geological Magazine (Decade 4) 2, 193-203.

Chilvers, H.A. 1929. Out of the Crucible. Cassell, London, 274 pp.

Committee of Enquiry [Malan, F.S., Maingard, L.F., Haughton, S.H., Fouché, L.] 1941. The Discovery of Gold on the Witwatersrand. Report of the Committee of Enquiry, appointed by the Commission for the Preservation of Natural and Historical Monuments, Relics, and Antiques. Government Printer, Pretoria, 55 pp.

Committee on British Petrographic Nomenclature [Watts, W.W., Campbell-Smith, W. et al.], 1921. Report of the Committee. Mineralogical Magazine 19, 137-147.

D.D. [i.e. David Draper] 1905. Discovery of gold on the Witwatersrand. An unrecorded incident. Original prospector deported. In: Rand Pioneers. Second Annual Report with Appendices. W.E. Burmester and Co., Johannesburg, p. 124. 
De Jager, F.S.J. 1986. The East Rand Goldfield and the South Rand Goldfield. In: Anhaeusser, C.R. (ed.). 1997. A Century of Geological Endeavour in Southern Africa. The Geological Society of South Africa, Johannesburg. pp. 111-171.

De Launay, L. 1896. Les Mines d'Or du Transvaal. Libraire Polytechnique, Baudry, Paris, 550 pp.

Dorsey, E.B. 1890. On the Witwatersrand Goldfields [abstract]. In: Report of the 59th Annual Meeting, Newcastle on Tyne, 1889. British Association for the Advancement of Science, London, 593.

Fitzpatrick, J.P. 1899. The Transvaal from Within. A private Record of Public Affairs. Heinemann, London and Frederick A. Stokes, New York, 452 pp.

Flett, J.S. 1937. The First Hundred Years of the Geological Survey of Great Britain. His Majesty's Stationery Office, London, $280 \mathrm{pp}$.

Frimmel, H.E. 1996. Witwatersrand iron-formations and their significance for gold genesis and the composition limits of orthoamphibole. Mineralogy and Petrology 56, 273-295.

Frimmel, H.E. 1997. Detrital origin of hydrothermal Witwatersrand gold - a review. Terra Nova 9, 192-197.

Geological Society of South Africa [undated]. Postcard titled 'Pioneers of Witwatersrand geology' [with photographic portraits of G.S. Corstorphine, J.S. Curtis, F.H. Hatch, E.T. Mellor, A.R. Rogers, A.R. Sawyer and R.B. Young].

Gibson, W. 1892. The Geology of the Gold-bearing and Associated Rocks of the Southern Transvaal. Quarterly Journal of the Geological Society of London 48, 404-437.

Goldmann, C.S., Kitchin, J. 1896. South African Mines; their Position, Results, and Developments: Together with an account of Diamond, Land, Finance and Kindred Concerns. I. Rand Mining Companies. Effingham Wilson, London; Argus Printing \& Publishing, Johannesburg, 583 pp.

Gray, E.L., Gray, J. 1940. A History of the Discovery of the Witwatersrand Goldfields. Sholto Douglas, Johannesburg, $335 \mathrm{pp}$.

Gray, J. 1937. Payable Gold. An initimate record of the history of the discovery of the payable Witwatersrand goldfields and of Johannesburg in 1886 and 1887. Based on Researches made in the State Archives, Pretoria by Ethel L. Gray and containing the Oosthuizen Papers which reveal the story of the discovery. Central News Agency, Johannesburg, 286 pp.

Gray, J., McLachlan, J.A. 1933. A history of the Introduction of the MacArthur-Forrest Cyanide Process to the Witwatersrand Goldfields. Journal of the Chemical, Metallurgical and Mining Society of South Africa 33, 375-395.

Greensmith, T.J. 1978. The Petrology of the Sedimentary Rocks. Unwin-Hyman, London, 262 pp. Greensmith, T.J. 1989. The Petrology of the Sedimentary Rocks. Chapman and Hall, London, 288 pp.

Greensmith, T.J., Hatch, F.H., Rastall, R.H. 1971. The Petrology of the Sedimentary Rocks. George Allen, London, 502 pp. 
Gregory, J.W. 1907. The Origin of the Gold in the Rand Banket. Transactions of the Institution of Mining and Metallurgy London 17, 2-41.

Gregory, J.W. 1911. Report of the Committee .... appointed to investigate and report on the Correlation and Age of South African Strata and on the Question of a Uniform Stratigraphical Nomenclature. In: Report of the 80th Annual Meeting, Sheffield, 1910. British Association for the Advancement of Science London, pp. 123-142.

Gunn, W., Clough, C.T., Hill, J.B. 1897. The geology of Cowal, including the part of Argyllshire between the Clyde and Loch Fine (With petrological notes by J.J.H. Teall and Dr. Hatch). Memoirs of the Geological Survey. Scotland. Her Majesty's Stationery Office, Edinburgh, 333 pp.

Hammond, J.H. 1895. The Future of the Rand. In: Hatch, F.H., Chalmers, J.A., The Gold Mines of the Rand, Being a Description of the Mining Industry of Witwatersrand, South African Republic. Macmillan, London and New York, pp. v-xi.

Hammond, J.H. 1935. The autobiography of John Hays Hammond. Farrar \& Rinehart, New York, 813 pp.

Handley, J.R.F. 2004. Historic overview of the Witwatersrand goldfields. Handley, Howick, KwaZulu-Natal, SA, 224 pp.

Harger, H.S. 1934. An early Transvaal geological map by Carl Mauch. Transactions of the Geological Society of South Africa, 37, 1-4.

Hatch, F.H. 1885a. Hypersthenandesit aus Peru. Neues Jahrbuch für Mineralogie, Geologie und Paläontologie 1885 (2), 73-78.

Hatch, F.H. 1885b. Ueber den Gabbro aus der Wildschönau in Tirol und die aus ihm hervorgehenden schiefrigen Gesteine. Zeitschrift für Kristallographie, Mineralogie und Petrographie, 7, 308360 .

Hatch, F.H. 1886. Ueber die Gesteine der Vulcan-Gruppe von Arequipa. Inaugural-Dissertation zur Erlangung der Doctorwürde bei der philosophischen Facultät der rheinischen FredrichWilhelms-Universität zu Bonn eingericht und mit den bergefügten Thesen vertheidigt am 15 Marz 1886. Holder, Vienna. Tschermak's mineralogischen und petrographischen Mittheilungen, 7, 308-360.

Hatch, F.H. 1888a. On a Hornblende-Hypersthene-Peridotite from Losilwa, a low hill in the Taveta District, at the S. Foot of Kilimanjaro, E. Africa. Geological Magazine (Decade 3) 5, 257-260.

Hatch, F.H. 1888b. Notes on the Microscopic Structure of some specimens from the district. In: Symes, R.G., Egan, F.W. and M'Henry, A. Explanatory Memoir to accompany Sheets 7 and 8 of the maps of the Geological Survey of Ireland, p. 40.

Hatch, F.H. 1888c. Petrographical Notes on the Igneous Rocks referred to in this Memoir. Appendix F. In: Hull, E., Cruise, R.J. Explanatory Memoir to accompany Sheets 138 and 139 of the Map of the Geological Survey of Ireland. Her Majesty's Stationery Office, Dublin, pp. 43-56.

Hatch, F.H. 1888d. On the Spheroid-bearing Granite of Mullaghderg, Co. Donegal. Quarterly Journal of the Geological Society of London, 44, 548-560. 
Hatch, F.H. 1888e. Glossary of Terms used in describing rocks. In: Teall, J.J.H. British Petrography: with special reference to the Igneous Rocks. Dulau, London, pp. 423-451.

Hatch, F.H. 1889a. On the Occurrence of Soda-Felsites (Keratophyres) in Co. Wicklow, Ireland. Geological Magazine (Decade 3) 6, 70-73.

Hatch, F.H. 1889b. Notes on the Wicklow Greenstones. Geological Magazine (Decade 3) 6, 261-265.

Hatch, F.H. 1889c. On the Lower Silurian Felsites of the south-east of Ireland. Geological Magazine (Decade 3) 6, 545-549.

Hatch, F.H. 1889d. Notes on the Petrographical Characters of some Rocks collected in Madagascar by the Rev. R. Baron. Quarterly Journal of the Geological Society of London, 45, 340-355.

Hatch, F.H. 1890. On the Lower Silurian felsites of the South-east of Ireland [abstract]. In: Report of the 59th Annual Meeting, Newcastle-upon-Tyne, 1889. British Association for the Advancement of Science, London, pp. 568-569.

Hatch, F.H. 1891a. On some West-Yorkshire Mica-trap dykes. In: Report of the 60th Annual Meeting, Leeds, 1890. British Association for the Advancement of Science, London, pp. 813814.

Hatch, F.H. 1891b. ['Observations' on the petrology of igneous rocks in the Silurian]. In: Dakyns, J.R., Tiddeman, R.H., Russell, R., Clough, C.T., Strahan, A. 1891. The geology of the country around Mallerstang with parts of Wensleydale, Swaledale and Arkendale (Sheet 97NW). Sheet memoir. Geological Survey of Great Britain (England and Wales). Old Series. His Majesty's Stationery Office, London, pp. 7, 13, 19-21,24-26, 31-33, 35.

Hatch, F.H. 1891c. An Introduction to the Study of Petrology: The Igneous Rocks. Swan Sonnenschein, London, $128 \mathrm{pp}$.

Hatch, F.H. 1891d. Vita. [Curriculum vitae and 'List of papers and books', 5 March 1891, submitted with application for membership of the Institution of Mining and Metallurgy, London, 7 July 1892].

Hatch, F.H. 1892a. A New British Phonolite. Geological Magazine (Decade 3) 9, 149-150.

Hatch, F.H. 1892b. Lower Carboniferous Rocks of East Lothian (Garlton Hills) Transactions of the Royal Society of Edinburgh, 37, 115-126.

Hatch, F.H. 1892c. The Physical Features and Geology of Borneo. Natural Science, 1, 108-116.

Hatch, F.H. 1892d. Text-book of Petrology: containing a description of the rock-forming minerals and a synopsis of the chief types of igneous rocks. 2nd edn. Swan Sonnenschein, London, 222 pp.

Hatch, F.H. 1892e. Mineralogy: The Characteristics of Minerals, their Classification and Description. Whittaker, London, 124 pp.

Hatch, F.H. 1894. Notes on the De Kaap Gold Fields, Transvaal Republic. South African Mining Journal 3, 304-305. 
Hatch, F.H. 1896. On the Auriferous Conglomerate of the Witwatersrand, Transvaal [abstract]. In: Report of the 65th Annual Meeting, Ipswich, 1895. British Association for the Advancement of Science, London, pp. 691-692.

Hatch, F.H. 1897a. Map of the Transvaal showing Physical Features and Political Divisions. Edward Stanford, London.

Hatch, F.H. 1897b. A Geological Map of the Southern Transvaal. Edward Stanford, London.

Hatch, F.H. 1897c. A Geological Survey of the Witwatersrand and other Districts in the Southern Transvaal [abstract and discussion]. Proceedings of the Geological Society of London, no. 681, $8-10$.

Hatch, F.H. 1898. A Geological Survey of the Witwatersrand and Other Districts in the Southern Transvaal [with notes on the plant remains by A.C. Seward]. Quarterly Journal of the Geological Society of London 54, 73-99.

Hatch, F.H. 1899. The Witwatersrand Mines and the Boer Government. Engineering Magazine 17, 812-817.

Hatch, F.H. 1902a. The Kolar Goldfield, being a Description of Quartz-Mining and Gold-Recovery as practiced in India. Memoir of the Geological Survey of India 33 (Part1), 1-72.

Hatch, F.H. 1902b. The Alpha and Phoenix mines in south-east Wainád. In: Hayden, H.H., Hatch, F.H. 1902. The Goldfields of Wainád, in Southern India. Memoir of the Geological Survey of India 33 (Part 2), 24-41.

Hatch, F.H. 1902c. Report on the property of the Società Eritrea le Miniere d'Oro. Società Eritrea le Miniere d'Oro, London.

Hatch, F.H. 1903a. A Geological Sketch Map of the Southern Transvaal. [1 inch: 4 miles $(1: 253,440)] .2$ nd edn. Stanford, London.

Hatch, F.H. 1903b. Explanatory Note to the Geological Map of the Southern Transvaal. Edward Stanford, London, 14 pp.

Hatch, F.H. 1903c. Notes on the Witwatersrand Gold Deposits and their Associated Rocks [discussion]. Journal and Proceedings of the South African Association of Engineers 2, 35-42.

Hatch, F.H. 1903d. On the Igneous Theory of the Hospital Hill Shales. Journal and Proceedings of the South African Association of Engineers 2, 191.

Hatch, F.H. 1903e. Notes on the Witwatersrand Beds, Transvaal. Geological Magazine, (Decade 4) $10,543-547$.

Hatch, F.H. 1903f. Text-book of Petrology containing a description of the rock-forming minerals and a synopsis of the chief types of igneous rocks. 3rd edn. Swan Sonnenschein, London, $222 \mathrm{pp}$.

Hatch, F.H. 1904a. The Extension of the Witwatersrand Beds Eastwards under the Dolomite and the Ecca Series of the Southern Transvaal. Transactions of the Geological Society of South Africa 7, 57-69. 
Hatch, F.H. 1904b. Discussion [Extension of the Witwatersrand Beds Eastwards under the Dolomitic and Chert Series]. Proceedings of the Geological Society of South Africa 7, 11-12.

Hatch, F.H. 1905a. [The 'Cullinan' diamond]. Proceedings of the Geological Society of London, no. $808,62$.

Hatch, F.H. 1905b. A Description of the Big Diamond recently found in the Premier Mine, Transvaal. Geological Magazine, New Series (Decade 5) 2, 170-172.

Hatch, F.H. 1905c. The Correlation between Pre-Karroo Beds of the Transvaal and Cape Colony [abstract]. In: Papers and Address [57th Meeting of the British Association for the Advancement of Science, South Africa] 2. South African Association for the Advancement of Science, Johannesburg, p. 10.

Hatch, F.H. 1905d. A New Instrument for Surveying Boreholes [abstract]. In: Papers and Address [57th Meeting of the British Association for the Advancement of Science. South Africa] 2. South African Association for the Advancement of Science, Johannesburg, p. 152.

Hatch, F.H. 1905e. British Association's Visit to Vereeniging. A Short Account of the Chief Points of Interest. Date of Excursion Friday, 1st September, 1905. Lewis \& Marks, Johannesburg, 6pp.

Hatch, F.H. 1905f. Text-book of Petrology containing a description of the rock-forming minerals and a synopsis of the chief types of igneous rocks. 4th edn. Swan Sonnenschein, London, 222 pp.

Hatch, F.H. 1906. The Geological History of South Africa. Geological Magazine (Decade 5) 3, 97 104, 161-168.

Hatch, F.H. 1907a. Presidential Address [The succession, thickness and geological history of the South African, and more especially of the Transvaal, formations]. In: Proceedings of the Geological Society of South Africa for 1906, Transactions of the Geological Society of South Africa 9, xxi-xxxiv.

Hatch, F.H. 1907b. A Visit to the Goldfields of Orenburg, Russia [with discussion]. Transactions of the Institute of Mining and Metallurgy 16, 300-304, 305, 309-310.

Hatch, F.H. 1908. 'Kimberlite' and the source of the Diamond in South Africa. Nature 77, 224-226.

Hatch, F.H. 1909a. Report of the Committee on Topographical and Geological Terms used locally in South Africa .... In: Report of the 78th Annual Meeting, Dublin, 1908. British Association for the Advancement of Science, London, pp 291-296.

Hatch, F.H. 1909b. Catalogue of a Collection of Rocks and Minerals from Natal and Zululand, arranged stratigraphically. Natal Government Museum, Pietermaritzberg, 71 pp.

Hatch, F.H. 1909c. Text-book of Petrology, containing a summary of the modern theories of petrogenesis, a description of the rock-forming minerals, and a synopsis of the chief types of igneous rocks and their distribution as illustrated by the British Isles. 5th edn. Swan Sonnenschein, London, 404 pp.

Hatch, F.H. 1910a. Report of the Committee on Topographical and Geological Terms used locally in South Africa .... In: Report of the 79th Annual Meeting, Winnipeg, 1909. British Association for the Advancement of Science, London, pp. 149-150. 
Hatch, F.H. 1910b. Report on the Mines and Mineral Resources of Natal (other than Coal). Richard Clay and Sons, London, 155 pp.

Hatch, F.H. 1911a. Supplementary Report. In: Gregory, J.W. Report of the Committee .... appointed to investigate and report on the Correlation and Age of South African Strata and on the Question of a Uniform Stratigraphical Nomenclature. Report of the 80th Annual Meeting, Sheffield, 1910. British Association for the Advancement of Science, London, pp. 123-142.

Hatch, F.H. 1911b. Report of the Committee .... appointed to determine the precise Significance of Topographical and Geological Terms used locally in South Africa .... In: Report of the 80th Annual Meeting, Sheffield, 1910. British Association for the Advancement of Science, London, pp. 160-165.

Hatch, F.H. 1911c. Notes on Natal Geology [abstract]. In: Report of the 80th Annual Meeting, Sheffield, 1910. British Association for the Advancement of Science, London, pp. 604-605.

Hatch, F.H. 1911d. The Past, Present and Future of the Gold-Mining Industry of the Witwatersrand, Transvaal by Frederick Henry Hatch, being The "James Forrest" Lecture delivered at The Institution of Civil Engineers, Session 1910-1911. Minutes of Proceedings of the Institute of Civil Engineers 186, 378-405.

Hatch, F.H. 1911e. Discussion [Secondary Enrichment at Huelva]. Transactions of the Institution of Mining and Metallurgy London 20, 72-3.

Hatch, F.H. 1911f. The Auriferous Conglomerates of the Witwatersrand. In: Foster Bain, H. (Ed.). Types of Ore Deposits, Mining and Scientific Press, San Francisco and Mining Magazine, London, pp. 202-219.

Hatch, F.H. 1912a. Description of a Diamantiferous Gem-Gravel from the West Coast of Africa. Geological Magazine, New Series (Decade 5) 9, 106-110.

Hatch, F.H. 1912b. Mineralogy. 4th edn. Whittaker, London and New York, 253 pp.

Hatch, F.H. 1913a. The Rand Banket [discussion]. Mining and Scientific Press, 21 Nov. 1913, 10191020. [In: Horwood, C.B. 1917. The Gold Deposits of the Rand. Charles Griffin, London, pp. 277-280].

Hatch, F.H. 1913b. [Grade] Impoverishment with Depth on the Rand [letter to editor]. Mining Magazine 9, 450-451.

Hatch, F.H. 1914a. Presidential Address [The Relation of Geology to Mining]. Transactions of the Institution of Mining and Metallurgy London 23, xli-lxvii; The Mining Journal 104, 295-297, 317-320; Economic Geology 9, 205-235.

Hatch, F.H. 1914b. The Rand Banket [discussion]. Mining and Scientific Press, 12 Jan 1914. In: Horwood, C.B. 1917. The Gold Deposits of the Rand. Charles Griffin, London, pp. 280-282.

Hatch, F.H. 1916. Mineralogy. 5th edn. Whittaker, London and New York, 258 pp.

Hatch, F.H. 1918a. Average Analyses of British Iron-Ores \& Ironstones produced in 1917-18, Together with a Note on the Sources of Supply, and the 1917 Figures for Production. The Iron and Steel Production Department. Ministry of Munitions of War [London], 11 pp. 
Hatch, F.H. 1918b. The Jurassic Ironstones of the United Kingdom - Economically Considered. Journal of the Iron and Steel Industry 97, 71-120.

Hatch, F.H. 1919a. The Iron and Steel Industry of the United Kingdom under War conditions. A record of the Work of the Iron and Steel Production Department of the Ministry of Munitions. Privately printed for Sir John Hunter, K.B.E., Director of Iron and Steel Production, Harrison, London [reprinted 1920], $167 \mathrm{pp}$.

Hatch, F.H. 1919b. Recent Iron-ore Developments in the United Kingdom. Nature, 103, 477-479.

Hatch, F.H. 1919c. Recent Iron-ore Developments in the United Kingdom. Geological Magazine (Decade 6) 6, 387-397.

Hatch, F.H. 1920a. The Development of Iron-Ore in Great Britain during the War. Economic Geology $15,328-338$.

Hatch, F.H. 1920b. The Iron Ore Supplies of the World. Geological Magazine 57, 504-517.

Hatch, F.H. 1921. The World's Copper Production. Geological Magazine 58, 32-40.

Hatch, F.H. 1922. The geology of the Far East Rand and the Heidelberg District, Southern Transvaal a Retrospect. Geological Magazine 59, 249-256.

Hatch, F.H. 1929. An Introduction to the Study of Ore-Deposits. George Allen and Unwin, London and University of Chicago Press, Chicago, 117 pp.

Hatch, F.H. 1931. Mineralogy. 6th edn. Sir Isaac Pitman, London, 262 pp.

Hatch, F.H., Chalmers, J.A., 1895. The Gold Mines of the Rand, Being a Description of the Mining Industry of Witwatersrand, South African Republic. Macmillan, London and New York, 306 pp.

Hatch, F.H., Corstorphine, G.S., 1904a. The Geology of the Bezuidenhout Valley and the District East of Johannesburg. Transactions of the Geological Society of South Africa 7, 97-109.

Hatch, F.H., Corstorphine, G.S., 1904b. The petrography of the Witwatersrand Conglomerates, with special reference to the origin of the gold. Transactions of the Geological Society of South Africa 7, 140-145.

Hatch, F.H., Corstorphine, G.S., 1905a. The Geology of South Africa. Macmillan, London, 348 pp.

Hatch, F.H., Corstorphine, G.S., 1905b. Reply to discussion [The petrography of the Witwatersrand Conglomerates, with special reference to the origin of the gold]. Proceedings of the Geological Society of South Africa 8, xxviii.

Hatch, F.H., Corstorphine, G.S., 1905c. The Cullinan Diamond. Transactions of the Geological Society of South Africa 8, 26-27.

Hatch, F.H., Corstorphine, G.S., 1905d. A Description of the Big Diamond recently found in the Premier mine, Transvaal. Geological Magazine, New Series (Decade 5) 2, 170-172. 
Hatch, F.H., Corstorphine, G.S., 1906. The Cullinan Diamond: a Description of the Big Diamond recently found in the Premier Mine, Transvaal. Annual Report Smithsonian Institution Washington 1905, 211-213.

Hatch, F.H., Corstorphine, G.S., 1909. The Geology of South Africa. 2nd. edn. Macmillan, London, $389 \mathrm{pp}$.

Hatch, F.H., Rastall, R.H. 1910. Dedolomitization in the Marble of Port Shepstone (Natal). Quarterly Journal of the Geological Society of London 66, 507-520.

Hatch, F.H., Rastall, R.H., 1913. Text-book of Petrology. Vol. II. The Petrology of the Sedimentary Rocks. A description of the sediments and their metamorphic derivatives, with an Appendix on the systematic examination of loose detrital sediments by T. Crook. George Allen, London, 425 pp.

Hatch, F.H., Rastall, R.H., Black, M. 1938. Text-book of Petrology. Vol. II. The Petrology of the Sedimentary Rocks. George Allen, London, 383 pp.

Hatch, F.H., Rastall, R.H., Greensmith, T.J. 1965. The Petrology of the Sedimentary Rocks. Murby, London, $408 \mathrm{pp}$.

Hatch, F.H., Vallentine, E.J. 1907. Mining Tables: being a comparison of the units of weight, measure, currency, mining area, etc. of different countries; together with tables, constants \& other data useful to mining engineers and surveyors. Macmillan, London and University Press, Glasgow, 200 pp.

Hatch, F.H., Wells, A.K., 1926. Text-book of Petrology. Vol. I. The Petrology of Igneous Rocks. 8th edn. George Allen and Unwin, London, 566 pp.

Hatch, F.H. Wells, A.K., Wells, M.K., 1949. The Petrology of the Igneous Rocks. 10th edn. Allen and Unwin. London, 469 pp.

Hatch, F.H. Wells, A.K., Wells, M.K., 1961. The Petrology of the Igneous Rocks. 12th edn. Allen and Unwin. London, 515 pp.

Hattersley-Smith, G. (Ed.) 1977. Foreign and Commonwealth Office. Antarctic Placenames Committee. Gazetteer of the British Antarctic Territory. Her Majesty's Stationery Office, London, $35 \mathrm{pp}$.

Hayward, C.L., Reimold, W.U., Gibson, R.L., Robb, L.J. 2005. Gold mineralization within the Witwatersrand Basin, South Africa: evidence for a modified placer origin, and the role of the Vredefort impact event. In: I. McDonald, A.J. Boyce, I.B. Butler, R.J. Herrington, D.A. Polya (Eds.) Mineral Deposits and Earth Evolution. Geological Society of London. Special Publications 248, 31-58.

Hocking, A. 1986. Randfontein Estates. The first hundred years. Hollards, Bethulie, 280 pp

Horwood, C.B. 1917. The Gold Deposits of the Rand. Charles Griffin, London, 400 pp.

Howarth, R.J. 2004. Hatch, Frederick Henry (1864-1932). In: H.G.C. Matthew and B. Harrison (Eds.) Oxford Dictionary of National Biography. Oxford University Press, Oxford. 25, 797-798. 
Jackson, S. 1970. The Great Barnato. Heinemann, London, 278 pp.

James, J.H.G. 1890. Description of the McArthur-Forrest system of treating tailings and refractory ores. Witwatersrand Mining and Metallurgical Review 1 (9 September), 4-5.

Jelenc, D.A. 1966. Mineral occurrences of Ethiopia. Ministry of Mines, Addis Ababa, 720 pp.

Jeppe, F. 1899. Map of the Transvaal or S.A. Republic and Surrounding Territories [6 sheets]. Edward Stanford, London.

Jones, M. 1993. From the archives. A compilation. Minerals Industry International, July 1993, 34-50.

Lednor, M. 1986. The West Rand Goldfield. In: Anhaeusser, C.R. (ed.). 1997. A Century of Geological Endeavour in Southern Africa. The Geological Society of South Africa, Johannesburg. pp. 49-109.

Leggett, T.H., Hatch, F.H. 1904. An Estimate of the Gold Production and Life of the Main Reef Series, Witwatersrand, down to $6000 \mathrm{ft}$. Transactions of the Institution of Mining and Metallurgy London 12, 39-46.

Letcher, O. 1936. The Gold Mines of Southern Africa. The History, Technology and Statistics of the Gold Industry. Privately published, Johannesburg and Waterlow, London, 580 pp.

Lezard, A. 1937. The great gold reef. The romantic history of the Rand goldfields. Bobbs-Merrill, Indianapolis, Indiana, $313 \mathrm{pp}$.

Lombaard, B.V. 1934. [Untitled comment on An early Transvaal geological map by Carl Mauch]. Proceedings of the Geological Society of South Africa, 37, xlviii-l.

McLea, J.H. 1909?. 'Rough sketch of the Rand as it was according to my notes and recollection in 1886 and early 1887.' [Drawn at some time between 1909 (latest note on map) and 1930; reproduced at original size as separate fold-out plate in: A.H. Smith (Ed.). 1956. Pictorial History of Johannesburg. City of Johannesburg Africana Museum. Frank Connock Publication no. 3. Juta, Johannesburg, 127 pp.]

Mendelsohn, R. 1991. Sammy Marks 'The Uncrowned King of the Transvaal'. David Philip, Cape Town and Ohio University Press, Athens, OH, 304 pp.

Molengraaff, G. A. F. 1895. Beitrag zur Geologic der Umgegend der Goldfelder auf dem Hoogeveld in der suid-afrikanischen Republik. Neues Jahrbuch für Mineralogie, Geologic, und Palaontologie (Beilage Band) 9, 174-292.

Moseley, 1906. Transvaal Coal. South African Mining Journal 4, 181.

Nutting, A. 1970. Scramble for Africa. The Great Trek to the Boer War. Constable, London, 454 pp.

Packenham, T. 1979. The Boer War. Weidenfeld \& Nicholson, London, 659 pp.

Phillips, G.N., Law, J.D.M. 1994. Metamorphism of the Witwatersrand gold fields: A review. Ore Geology Reviews 9, 1-31.

Phillips, G.N., Law, J.D.M., Stevens, G. 1997. Alteration, heat, and Witwatersrand gold: 111 years after Harrison and Langlaagte. South African Journal of Geology 100, 377-392. 
Phillips, G.N., Myers, R.E., Law, J.D.M., Bailey, A.C., Cadle, A.B., Beneke, S.D., Giusti, L. 1989. The Witwatersrand Gold Fields: I. Postdepositional History, Synsedimentary Processes, and Gold Distribution. Economic Geology Monograph 6, 585-597.

Posewitz, T. 1889. Borneo: Entdeckungsreisen und Untersuchungen: gegenwärtiger Stand der geologischen Kenntnisse: Verbreitung der nutzbaren Mineralien. R. Friedländer und Sohn, Berlin, 385 pp.

Posewitz, T. 1892 Borneo: its Geology and Mineral Resources. Translated from German by Frederick H. Hatch. Edward Stanford, London, 495 pp.

Preller, G.S. 1935. Argonauts of the Rand. Story of the discovery of the Main Reef, with the Marais Diary (1849-65). Wallachs Drukkery en Uitgewers Mpy., Pretoria, 200 pp.

Pretorius, D.A. 1975. The Depositional Environment of the Witwatersrand Goldfields: A Chronological Review of Specualtions and Observations. Minerals Science and Engineering 7, $18-47$.

R. H. R. [i.e. R.H. Rastall], 1932. Dr. F.H. Hatch. Nature, London 130, 602.

Rickard, T.A. 1922. Henning Jennings An Interview. In: Rickard, T.A., Interviews with Mining Engineers. Mining and Scientific Press, San Francisco, pp. 221-253.

Rogers, A.W. 1937. The Pioneers in South African Geology and Their Work. Transactions of the Geological Society of South Africa. Annexure to Volume 39, 1-139.

Rosenbusch, C.H.F. 1888. Hülfstabellen zur mikroskopischen Mineralbestimmung in Gesteinen. Schweizerbart, Stuttgart. 2 pp +9 double-sided tables.

Rosenbusch, C.H.F. 1890 Petrographical Tables. An aid to the Microscopical Determination of Rockforming Minerals. Translated and edited (with the author's permission) by Dr. F.H. Hatch. Swan Sonnenschein, London, 2 pp. +9 double-sided tables.

Sawyer, A.R. 1889. The Northern extension of the Witwatersrand Gold-field. Transactions of the North Staffordshire Institute of Mining and Mechanical Engineers 10, 124-152.

Seward, A.C. 1898. Notes on the Plant-Remains. In: Hatch, F.H. A Geological Survey of the Witwatersrand and Other Districts in the Southern Transvaal. Quarterly Journal of the Geological Society of London 54, pp. 92-93.

Skinner, W.R. 1897. The Mining Manual for 1896. Privately published. London.

Società Eritrea per le Miniere d'Oro. 1902. Relazioni del Consiglio d'Amministrazione e dei Sindaci e situazione dei conti al 31 dicembre 1901, primo esercizio. Società Eritrea per le Miniere d'Oro, Rome; Reports of the Board of Directors and the Board of Statutory Auditors and situation of auditors to December 31, the first year, Società Eritrea per le Miniere d'Oro, London.

Solly, R.H., Smith, G.F.H. 1912, Hatchite, a new (anorthic) mineral from the Binnenthal, Mineralogical Magazine 16, 287-289.

Struben, H.W. (Ed., E. Struben) 1920. Recollections of Adventures. Pioneering and development in South Africa, 1850-1911. T. Maskew Miller, Cape Town and Basil Blackwell, Oxford, 208 pp. 
Technical Education Commission. 1903. [Transvaal] Technical Education Commission. Report. Government Printer. Pretoria.

The Editor [E.P. Rathbone]. 1890. "Deep Level" Properties. Witwatersrand Mining and Metallurgical Review 1 (10), 7-11.

Therriault, A.M., Reimold, W.U., Reid, A.M. 1997. Geochemistry and impact origin of the Vredefort Granophyre. South African Journal of Geology 100, 115-122.

Thomas, A. 1996. Rhodes. The Race for Africa. BBC Books. London, 367 pp.

Trewartha-Jones, W.H. 1915. [Vote of thanks to Dr. Hatch]. In: Report of the $24^{\text {th }}$ Annual General Meeting. Transactions of the Institution of Mining and Metallurgy London 24, xxviii.

Truscott, S.J. 1898. The Witwatersrand Goldfields. Banket and Mining Practice. Macmillan, London and New York, 495 pp.

W.C.B. [i.e. W.C. Burnet] (Ed.). 1890. The Emigrants' Guide to South Africa, including Cape Colony; the Diamond Fields, Bechuanaland, Transvaal; the Goldfields, Natal, the Orange Free State, and the Territories of the British South Africa Co., containing a mass of useful and valuable information, with map. 6th edn. A. White \& Co., London, 139 pp.

W.G. [?Walcot Gibson] 1905. The Geology of South Africa [review]. Geological Magazine (decade 2) 2, 413-414.

Webb, H.H. 1903. Discovery and History of Witwatersrand Goldfields. Proceedings, South African Association of Engineers.

Werdmüller, V.W. 1986. The Central Rand. In: Antrobus, E.S.A. (ed.) Witwatersrand gold - 100 Years. A review of the discovery and development of the Witwatersrand Goldfield as seen from the geological viewpoint. The Geological Society of South Africa, Johannesburg. pp. 7-47.

Williams, E. 1905. Geology. In: Bell, H.T.M., Lane, C.A. (Eds.) A Guide to the Transvaal. British Association for the Advancement of Science. Johannesburg meeting 1905. Bartholomew \& Lawlor, Johannesburg. pp. 244-256.

Wilson, H.W. 1900. With the Flag to Pretoria. A History of the Boer War of 1899-1900. Harmsworth, London $716 \mathrm{pp}$.

Young, R.B. 1917. The Banket - A Study of the Auriferous Conglomerates of the Witwatersrand and the Associated Rocks. Gurney \& Jackson, London, 125 pp .

Zaccaria, M. 2005. L'oro dell'Eritrea. Africa, 60, 65-110. 